\title{
An Antipodean Phenomenon: Comparing the Labo(u)r Party in New Zealand and Australia
}

\section{Ray Markey*}

The New Zealand Labour Party (NZLP) and the Australian Labor Party (ALP) share many similarities in terms of their ideology, support base and electoral performance. Labour and ideas travelled regularly between New Zealand and Australia. Australian influence was evident in the early NZLP leadership, and New Zealand influenced ALP policy regarding arbitration and age pensions. Subsequently, the NZLP and ALP have enjoyed similar national electoral records and followed broadly similar policies. However, there were always important divergences, particularly in terms of the timing of consolidation and formation of government, the impact of different state structures, the degree of support from farmers, and racial policy. This article surveys the parameters of the shared experience through examining the two parties' political and social environments, their support bases and their ideology and policy.

The political trajectory of the Australian Labour Party (ALP) and the New Zealand Labour Party (NZLP) has been remarkably concurrent, with substantial convergence in their class nature, ideology and support base over time. Both parties have been the main working-class political organisations in their respective countries, notwithstanding challenges from the left. Unions played a key role in their formation, and continue to exert a major influence as affiliated bodies in their extra-parliamentary party apparatus. ${ }^{1}$ Both parties' political praxis has been dominated by parliamentaryoriented pragmatism, without ever adopting the Marxist platforms of Europeanstyle Social Democratic Parties in the late nineteenth century. In the 1980s, when in government, both parties also adopted market-oriented economic reform agendas. Even the parties' record of achieving national government has been remarkably similar. Of course, in many of these respects a similar congruence has been observed for both the ALP and NZLP with the British Labour Party (BLP). ${ }^{2}$ The shared British legacies of ethnicity and legal, political and trade union structures clearly influenced the manifestation of working-class political organisation in particular shared ways.

However, the convergence between the ALP and NZLP has arguably been greater than for either party with the BLP. The formative periods of the antipodean parties in particular were characterised by a substantial trans-Tasman community of labour. At an organisational level this was expressed in the leadership of the early parties. For example, the first ALP Prime Minster of Australia, John Christian Watson, was born in Chile but brought up in New Zealand before migrating to Australia in 1888 at the age of 21 . He became an active labour leader soon afterwards. ${ }^{3}$ Harry Holland, the firebrand socialist in the Sydney labour movement during the 1890s, emigrated to New Zealand and led the NZLP from 1919 until his death in $1933 .{ }^{4}$ The first NZLP Prime Minister, Michael Savage, was Australian-born, as were four others in his Cabinet. ${ }^{5}$ The leaders of the early Tasmanian ALP were also strongly influenced by their New Zealand political experience. ${ }^{6}$ To this day the ALP and NZLP exchange expertise, particularly during elections. 
Trade unions in each country arguably enjoy closer ties than the parties, based on a longstanding community of labour. Organisers from the Australian Seamen's Union formed a New Zealand seamen's union in 1880, and the Amalgamated Shearers Union (ASU) organised New Zealand shearers in the 1880s. In the late 1880s a New Zealand Maritime Council of unions affiliated to the Maritime Council in Australia, and subsequently New Zealand unions were drawn into the great Maritime Strike which afflicted the Australian colonies in 1890. At the leadership level, Arthur Rae was born in New Zealand before becoming a leader of the ASU and Australian Workers Union in the 1880s to 1890s, and subsequently an ALP Senator. Much of the militant leadership of the New Zealand Federation of Labour (NZFOL), the 'Red Feds', formed in 1909, was Australian, including Bob Semple, Michael Savage and Harry Holland. ${ }^{7}$ Most of these unionists became political leaders.

The organisational community of labour brought a cross fertilisation of ideas. At the policy level the notion of compulsory state arbitration moved backwards and forwards across the Tasman, gathering a little in momentum each time before being enacted in both countries, in 1894 in New Zealand and 1901-04 in Australia. ${ }^{8}$ More generally, Edward Bellamy's utopian Looking Backward was the most influential socialist tract in both countries in the 1880s and 1890s, as well as in the United States. Similarly, Henry George's Progress and Poverty, revealing the 'unearned increment' accruing to landowners as the cause of social inequality, was influential in the labour movement on both sides of the Tasman, especially after his visit to Australia in 1890, and the Knights of Labour also spread from the USA to Australia and New Zealand. These shared influences indicated the wider diffusion of ideas throughout the Pacific Rim between the great new settler society cities of San Francisco, Los Angeles, Sydney, Melbourne and Auckland. The labour press in eastern Australia and New Zealand manifested and embraced this wider community of labour, notably in the Boomerang, the Worker and the Australian Workman, where William Lane the socialist journalist popularised Bellamy, George and other radical authors for the Queensland and New South Wales (NSW) labour movements during 1887-93.9

The mutual influence of the Australian and New Zealand labour movements is hardly surprising given the socio-economic context from which they emerged. A trans-Tasman labour market characterised many occupations, notably seafaring, shearing and mining. In many respects it was a wider transnational labour market, with workers moving between the settler societies of the Pacific Rim, South Africa and Britain. ${ }^{10}$ The leadership of the labour movement in both countries clearly indicated these wider influences. ${ }^{11}$ Secondly, Australia and New Zealand shared close proximity to each other at the end of the earth, the antipodes, equally isolated from the civilised world of Europe from which most of their population came. They shared British colonial histories and economic bases exporting primary commodities, especially wool, to Mother England. Both developed entrepreneurial, economically interventionist states which played key roles in rapidly developing infrastructure. ${ }^{12}$ Only at the last moment did New Zealand finally decide not to join the federation that created the Commonwealth of Australia in 1901, as Western Australia eventually decided to join. Auckland is closer to Sydney and Melbourne than Perth is to either, although joining the Commonwealth lacked popular support. ${ }^{13}$

More importantly for labour's political organisation, Australia and New Zealand shared democratic political environments at the end of the nineteenth century, which nurtured working-class political and industrial organisation. New Zealand enacted 
universal suffrage in 1893, the first country in the world. Australia introduced full European suffrage nationally in 1902 and in the states between 1894 and 1908, although not all Aboriginals received the vote until 1962. ${ }^{14}$ For their advanced political and social legislation Australia and New Zealand earned reputations as the 'social laboratories of the world' at the beginning of the twentieth century. ${ }^{15}$

The remainder of this article examines the nature of the ALP and NZLP in more detail. It considers the impact of different structures of the state and political environment, and compares the timing and process of party formation, the ALP and NZLP's changing electoral base over time, and the parties' ideology and policy. It concludes with a basis of explanation for the convergences and divergences between the parties.

\section{Structure of the State and Political Environment}

A major difference in the environment in which the parties operated was the structure of the state. Australian federalism contrasts with the centralist New Zealand structure. The federal Australian structure has significantly reduced opportunities for development of national economic policy because of national government's limited constitutional powers in this sphere. Yet, by constituting an extra political layer between the national and the local, state governments and public institutions have provided the ALP with an expanded range of opportunities for government, political experience, funds, influence and appointments to public institutions such as arbitration tribunals. The ALP has formed governments for over 50 years of its history in NSW, Tasmania and Queensland, partially compensating for a weaker national electoral performance, especially since the Australian Constitution gave an important role to the state level of government in issues of primary concern for the ALP: industrial relations, welfare provision, education and health. The states have also traditionally provided extensive employment in various public authorities and corporations, such as the railways. As with many other Australian institutions such as unions, the ALP itself mirrors the state in its federal structure, with a major role for the state branches of the party. ${ }^{16}$

Other differences in the structure of the political environment may have impacted on both parties. First, Australia's system of compulsory voting, introduced in 1925 at the national level, has frequently been considered to offer an advantage to the ALP, because its supporters generally have lower socio-economic status and a reduced probability of voting in a voluntary system according to surveys. ${ }^{17}$ Second, Australia's system of preferential or alternative voting has also had an impact on the ALP's electoral record at times. Generally, the system has allowed candidates from both conservative parties, Liberal and Country/National to contest the same seats and maximise the total conservative vote, without splitting the vote because of an exchange of preferences between them. During the 1950s and 1960s the ALP was disadvantaged by the distribution of Democratic Labor Party preferences to the conservative coalition of the Liberal and Country Parties, and in 1961 and 1969 this lost the national elections for the ALP. During the 1990s the ALP was advantaged by distribution to it of preferences from minor centre-left parties, notably the Greens and Democrats, enabling the ALP to win the 1990 election. ${ }^{18}$

Third, New Zealand abolished its upper house of parliament, the Legislative Council, in 1950 on the initiative of a National government. ${ }^{19}$ This contrasted with 
Australia, where governments have rarely controlled the proportionally elected national Senate, which created great difficulties in achieving the ALP's reform agenda during its government of $1972-75 .{ }^{20}$ In addition, abolition of the state upper houses was a longstanding ALP policy until they became democratically elected, beginning with South Australia in the early 1970s, and elsewhere in the 1980s. Only in Queensland did the ALP succeed in abolition in 1922. The motive for ALP policy had been that the upper houses had been conservative bastions against reform. ${ }^{21}$ The New Zealand upper house behaved less consistently in this manner, but in the 1980s and 1990s its absence possibly facilitated radical economic deregulation by the NZLP and the Nationals. Finally, New Zealand's subsequent implementation of a Mixed Member Proportional voting system in 1996 created a seemingly perpetual need for coalition governments between one of the major parties and minor parties advantaged by proportional representation. This has probably acted as a constraint for NZLP governments since 1999. ${ }^{22}$

\section{Formation of the ALP and NZLP}

The ALP and NZLP are each the oldest political party in their respective countries. The relatively early growth of trade unions provided leadership and an organisational base amongst workers. By 1913 the membership of Australian and New Zealand unions represented 34 and 15 per cent of their respective workforces, respectively the most and third most unionised societies in the world. ${ }^{23}$

Union defeat in major strikes which spread widely from the maritime industry and involved widespread use of police, special constables and the military, also played a key role in the formation of both parties. In Australia the Trades and Labour Councils (TLCs) of Sydney, Brisbane, and Adelaide, the Melbourne Trades Hall Council and the Australian Labour Federation (ALF) in Queensland took preliminary steps towards formation of a workers' political party from the late 1880s. But it was the defeat of the unions in the great 1890 Maritime Strike that provided the final momentum for widespread union and mass electoral support, with the aim of preventing the state apparatus of the law and military being used again on the side of employers, and achieving by political ends the industrial reforms, such as an eight-hour day, which the unions had failed to generalise with industrial action. From late 1890 to 1891 Labor parties under various names were formed to contest elections in the colonies of NSW, Queensland, South Australia and Victoria. ${ }^{24}$

Similarly, the great 1913 strike in New Zealand, which also began in the maritime industry, played a pivotal role in finally overcoming divisions between moderates and militants to form the united NZLP in 1916. The orthodox interpretation of the 1913 strike's role in the formation of the NZLP is remarkably similar to that in Australia in relation to 1890 . In both cases the major strikes formed part of a series of major industrial confrontations which have been commonly depicted as expressions of broadly based and growing class conflict. In each case, the industrial defeat of the labour movement encouraged political organisation to overcome its weaknesses and neutralise the state apparatus in industrial disputes. ${ }^{25}$ Patrick O'Farrell challenged this interpretation to suggest that the new NZLP of 1916 represented an attempt to implement militant socialism in a democratic political context, on the grounds principally that the new NZLP leadership came from the militants. ${ }^{26}$ Nevertheless the militant leadership acted consistently with the orthodox interpretation. 
A key difference between the two parties, however, was the timing of their formation and consolidation. The early colonial labour parties in Australia were remarkably successful in rapidly establishing an electoral presence. Labor returned members in 1891 in the first elections it contested in South Australia and NSW, in sufficient numbers to hold the balance of power in NSW. In 1893 in the first general elections contested in Queensland, Labor emerged as the second largest party in parliament, and in 1899 formed a brief minority government, the first Labor government in the world. With the federation of the Australian colonies into states of the Commonwealth of Australia in 1901, the ALP immediately emerged as a major national force, briefly forming a minority national government in 1904. By 1910 the ALP formed majority governments nationally and in NSW and South Australia. It was largely in response to the ALP threat that anti-Labor political forces developed a fully-fledged party structure, commencing with the 'fusion' of Free Traders and Protectionists into the Liberal Party in 1909. ${ }^{27}$

The later emergence of the NZLP begs the question 'why?', especially since the New Zealand unions also experienced the shock of defeat in the 1890 Maritime Strike when it spread across the Tasman Sea. One answer lies in the socially reformist nature of the ruling Liberal Party from 1891 to 1912, which effectively operated as a Lib-Lab alliance with organised labour's support after the 1890 strike. In 1891 five of the government's members claimed to be Labour representatives. Liberal policies for economic infrastructure development, graduated income taxes, breaking-up large rural estates, recognition of unions, and welfare provision, notably the old age pension, attracted a broad electoral alliance of small traders, urban professionals, small and especially leasehold farmers, employers, unionists, and skilled and unskilled workers generally. Organised labour was particularly attracted by industrial legislation under the Minister for Labour from 1893-95, William Pember Reeves, including the Industrial Conciliation and Arbitration Act 1894, which recognised unions and provided for arbitration of disputes, and the Factories Act 1894, which regulated working conditions. ${ }^{28}$

In Australia Lib-Labism also was the dominant parliamentary modus operandi for the Labor Parties in Victoria and South Australia during the 1890s, for reasons similar to New Zealand, since Liberal governments in Victoria and South Australia were amenable to reform. This was especially the case in Victoria, because of the dominance of the labour movement there by two groups. The first group consisted of conservative craft unions politically allied with liberal protectionist employers with whom they shared an interest in protecting local manufacturing through tariffs. These employers thus provided employment and could afford a fair wage because they did not need to compete so strongly on the basis of labour costs. The second significant group consisted of the Amalgamated Miners Association, whose membership consisted of many independent gold miners. ${ }^{29}$ In NSW and Queensland the economy was more export-oriented and free trade was consequently a significant issue dividing non-Labor political forces, and liberalism was less entrenched. The labour movements themselves were divided over free trade versus protectionist policies, and less dominated by conservative craft unions as a result of greater organisation amongst wage-earning miners, and the unskilled generally, particularly rural workers. Consequently, the Labor Parties in NSW and Queensland developed more independently than in other colonies, and after 1901 provided the model for the ALP at a national level..$^{30}$ 
The second factor delaying the emergence of the NZLP lay in divisions within the labour movement. These emerged as a result of a growing rift between the labour movement and the Liberal government from the late 1890s, fuelled by the growing dissatisfaction of the labour movement with the arbitration system and the decline in real wages. ${ }^{31}$ Liberal government amendments to the Arbitration Act also eroded union power, in 1905 making it illegal for unions to strike while an award was still operative, ${ }^{32}$ and in 1908 increasing penalties for strikes and lockouts. At the same time, rapid union growth encouraged the rise of an increasingly independent labour movement, as it had in Australia in the 1880s. Most of the growth during this time was driven by the unionisation of unskilled workers especially in the cities of Auckland and Wellington. ${ }^{33}$

As the labour movement began to assert its independence it became divided into two camps: TLC moderates, based predominantly on craft unions, and militant 'Red Feds', based on miners and unskilled workers. The first camp emerged from the 1904 conference of TLCs, which supported the formation of the Independent Political Labour League (IPLL), and was succeeded by the first national NZLP in 1910, and by the United Labour Party (ULP) in 1912. The IPLL and NZLP each gained one member of parliament, but there was a handful of independent labour members from this era as well. ${ }^{34}$

The second camp manifested itself politically through the Socialist Party and industrially through the NZFOL. The Socialist Party was a loose alliance of autonomous groups from 1901 in Wellington, Auckland, Petone and Christchurch. ${ }^{35}$ It did not contest elections on a united national front until 1908. In that year miners in the west coast town of Blackball successfully struck for an extension of lunchtime from 15 to 30 minutes, although the Arbitration Court fined them. ${ }^{36}$ Immediately following the Blackball strike the New Zealand Federation of Miners was established at a conference in Greymouth. At its second conference in 1909, the organisation was renamed the New Zealand Federation of Labour (nicknamed the 'Red Federation') to broaden support by attracting those unions disgruntled with the TLCs. The 'Red Feds' membership overlapped with the Socialist Party. They favoured industrial action over political, as they were strongly influenced by the syndicalism of the Industrial Workers of the World (IWW), but mainly by the De Leonite variety which did countenance political organisation. IWW influences were due to an influx of ideas and leadership personnel from the United States and Australia. Their main aim was supplanting the arbitration system with direct bargaining with employers. ${ }^{37}$ These divisions in the New Zealand labour movement split substantial total labour votes in urban centres, which was particularly damaging in a two ballot system, ${ }^{38}$ until the unity achieved in 1916.

In its formative years the ALP also experienced divisions, particularly in NSW. These occurred between parliamentarians and the extra parliamentary party in NSW in the mid-1890s; between the rural Australian Workers Union (AWU) and the TLCs and parliamentary party on a number of occasions from the 1890s onwards; and between parliamentary moderates and more militant socialists in the mid-1890s, during World War I and in the 1920s. ${ }^{39}$ However, during the seminal years such divisions were contained within the party except for a brief period in NSW in 189495. The split over conscription during World War I which led to the downfall of ALP governments nationally and in NSW, was more significant. ${ }^{40}$ In contrast, whilst there 
were also splits in the New Zealand labour movement over conscription in World War I, the NZLP did not have the responsibility of government and consolidated its position as a result of its anti-conscription stance, which linked militants with moderate anti-conscriptionists. ${ }^{41}$

A third critical factor which explains the later consolidation of the NZLP as an electoral force lies in the role of class structure and consciousness. A key explanation for the emergence of labour parties in both countries has been the development of a substantial working-class and a rising-class consciousness in the period prior to the formation of parties. This resonates with the argument of Hobsbawm and others for the British Labour Party, although recent British scholarship has also stressed the role of the party in creating class consciousness to provide an electoral base for itself..$^{42}$ Both arguments can be demonstrated simultaneously for the Australian and New Zealand parties. However, the timing of class formation and consciousness differed.

Australia experienced a structural shift during the second half of the nineteenth century towards an industrial-commercial society with the working class representing about 75 per cent of the population by 1914. Although the pastoral industry and mining remained important, manufacturing grew substantially, particularly in NSW and Victoria. Between 1871 and 1914 the proportion of the workforce employed in the primary industry sector (including mining) fell from over 40 per cent of breadwinners to about 30 per cent, whilst those employed in secondary industry (including building) rose from about 25 to 30 per cent, and those in commerce, transport and communications from 12 to 23 per cent. Manufacturing lacked a heavy industrial base, craft organisation in much manufacturing remained important and outwork was the major source of growth in the clothing industry. However, the size of factories almost doubled from 1881 to 1901 in NSW and Victoria, and some large establishments operated in metals, machinery and engineering, together with woollen mills, sugar refineries and gas works. The structural shift also involved a closing of opportunity for working men's independence on the land or as independent miners, and in urban crafts the opportunity for independence as a small master also receded by the end of the century. These trends provided the numerical basis for political organisation, but the rising class consciousness which occurred at the end of the century was also required. This was evident partly in the rapid excited growth and articulation of unionisation from the 1880s, involving unskilled workers in mines, the maritime industry, road and rail transport and the pastoral industry as well as the traditional craft unions. The language of industrial relations in the press was increasingly couched as 'capital versus labour', radical and socialist ideas were prominent amongst workers, promulgated through a vigorous radical press, and embryonic workers' political organisations appeared. ${ }^{43}$

New Zealand followed a similar trajectory, but on a smaller scale and later than Australia. Union membership grew dramatically in the late 1880s, but dissipated quickly under the pressures of the depression and defeat in the 1890 Maritime Strike. New Zealand unions actually began recovery quicker than their Australian counterparts because the New Zealand arbitration system assisted them from 1894. However, New Zealand society was more fluid for a longer period than in Australia, offering greater opportunity for social mobility. In part this reflected the smaller scale of industry. ${ }^{44}$ Olssen observes for 1914 that despite the growth in industry in large towns, 'self employment remained a viable goal for artisans in many 
trades' ${ }^{45}$ at a time when these opportunities had receded substantially in Australia. Furthermore, Fairburn argued that spatial fragmentation in New Zealand hindered the development of political class consciousness amongst workers. ${ }^{46}$ Although space was even greater in Australia, there was a greater concentration of the working class in the capital cities of each colony. When class consciousness was demonstrated substantially in New Zealand, it was associated with the mass unionisation of the unskilled from 1905 to 1911 for the first time since 1889-90, and the emergence of the militant Red Feds. However, the syndicalism of the Red Feds to some extent hindered political organisation by labour, particularly in 1911-13 during the period of greatest influence of the anti-political Chicago-style IWW (the 'bummery') within the Red Feds. ${ }^{47}$

Fourthly, the role of the Irish should not be underestimated. In Australia the Irish provided an important mass base for the labour movement. They accounted for over a quarter of the immigrant population in 1891 when the Labor Party was formed, concentrated in unskilled labouring occupations. Irish distinctiveness was accentuated by religious difference, with up to 90 per cent being Roman Catholic, accounting for the bulk of the 26 per cent of the population of this persuasion in NSW in $1901 .^{48}$ Irish separateness contributed to class consciousness because of their working-class concentration, and they played a disproportionately significant role in Labor Party affairs, especially in NSW..$^{49}$ The anti-conscription stance of the ALP during World War I was bolstered by this influence after the brutal repression of the 1916 Easter uprising in Ireland.$^{50}$ In contrast, the New Zealand Irish were less numerous, accounting for only 14 per cent of the electorate in the early 1920s, and a higher proportion were Protestant, and inclined to conservative politics, than in Australia. ${ }^{51}$ They were also less socially separate than in Australia at the formative stages of labour's political organisation..$^{52}$

\section{Electoral Success, Class Structure and Party Membership}

At the beginning of 2008 the ALP and NZLP had held office for almost identical total periods since their formation: 35.58 and 34.25 years respectively. Table 1 shows the periods of national office for both parties. The main points of departure were the later electoral success for the NZLP, and the greater experience of office gained at state level by the ALP.

Both the ALP and the NZLP attained parliamentary office when they emerged with mass working-class electoral support, in 1910 and 1935 respectively. In both cases this base was built up in a relatively short time, over about 20 years from their inception: 1890-1910 for the ALP, and 1916-35 for the NZLP. The process of this development, however, was uneven. At a national (or state) level the percentage of the vote gained increased very rapidly at the end of these developmental periods. What national percentages hide, however, is the importance of the development of party and union networks at a local level. Although both parties always gained strong support from urban and mining working-class electorates, there were many working-class areas where they did not initially gain support. Both parties had to contend with popular locally embedded members of parliament (MPs) who had reputations as 'workingmen's friends' or were former union leaders. ${ }^{53}$ Arguably for the NZLP this was a longer term process, which began in 1904 with the formation of the IPLL. 
Table 1: Periods of NZLP Governments and ALP State and Commonwealth Governments, 1901-2007

\begin{tabular}{|c|c|c|c|c|c|c|c|}
\hline $\begin{array}{l}\text { C'wealth } \\
\text { Australia }\end{array}$ & $\begin{array}{l}\text { New } \\
\text { South } \\
\text { Wales } \\
\end{array}$ & Victoria & $\begin{array}{l}\text { Queens- } \\
\text { land }\end{array}$ & $\begin{array}{c}\text { South } \\
\text { Australia }\end{array}$ & $\begin{array}{l}\text { Western } \\
\text { Australia }\end{array}$ & Tasmania & $\begin{array}{c}\text { New } \\
\text { Zealand }\end{array}$ \\
\hline $\begin{array}{c}1904 \\
3.5 \text { mths }\end{array}$ & & $\begin{array}{l}1913 \\
2 \mathrm{wks}\end{array}$ & & $\begin{array}{c}1905-09 \\
3 \text { yrs/10 } \\
\text { mths }\end{array}$ & $\begin{array}{c}1904-05 \\
1 \mathrm{yr} / 5 \mathrm{mths}\end{array}$ & $\begin{array}{l}1909 \\
1 \mathrm{wk}\end{array}$ & \\
\hline $\begin{array}{l}1908-09 \\
5.5 \text { mths }\end{array}$ & $\begin{array}{c}1910-16 \\
6 y r s / 2 \\
\text { mths }\end{array}$ & $\begin{array}{c}1924 \\
5 \text { mths }\end{array}$ & $\begin{array}{c}1915-29 \\
14 \text { yrs }\end{array}$ & $\begin{array}{c}1910-12 \\
1 \mathrm{yr} / 8.5 \\
\text { mths }\end{array}$ & $\begin{array}{l}1911-16 \\
4 \text { yrs/10 } \\
\text { mths }\end{array}$ & $\begin{array}{c}1914-16 \\
2 \text { yrs }\end{array}$ & \\
\hline $\begin{array}{c}1910-13 \\
3 \text { yrs/2 } \\
\text { mths }\end{array}$ & $\begin{array}{c}1920-22 \\
2 \text { yrs }\end{array}$ & \begin{tabular}{|c|}
$1927-28$ \\
$1 \mathrm{yr} / 6 \mathrm{mths}$
\end{tabular} & & $\begin{array}{c}1915-17 \\
2 \text { yrs/3.5 } \\
\text { mths }\end{array}$ & & $\begin{array}{c}1923-28 \\
4 \text { yrs/8.5 } \\
\text { mths }\end{array}$ & \\
\hline $\begin{array}{c}1914-16 \\
2 \text { yrs/2 } \\
\text { mths }\end{array}$ & $\begin{array}{c}1925-27 \\
2 \text { yrs/4 } \\
\text { mths }\end{array}$ & $\begin{array}{c}1929-32 \\
2 \text { yrs/6 } \\
\text { mths }\end{array}$ & & $\begin{array}{c}1924-27 \\
3 \text { yrs }\end{array}$ & $\begin{array}{c}1924-30 \\
6 \text { yrs }\end{array}$ & & \\
\hline $\begin{array}{c}1929-32 \\
2 \text { yrs/2 } \\
\text { mths }\end{array}$ & $\begin{array}{c}1930-32 \\
1 \mathrm{yr} / 6 \mathrm{mths}\end{array}$ & $\begin{array}{l}1943 \\
4 \text { days }\end{array}$ & $\begin{array}{c}1932-57 \\
25 \mathrm{yrs} / 2 \\
\text { mths }\end{array}$ & $\begin{array}{c}1930-33 \\
3 \text { yrs }\end{array}$ & $\begin{array}{c}1933-47 \\
14 \mathrm{yrs} / 1 \\
\mathrm{mth}\end{array}$ & $\begin{array}{c}1934-69 \\
35 \mathrm{yrs}\end{array}$ & $\begin{array}{c}1935-49 \\
14 \text { yrs }\end{array}$ \\
\hline $\begin{array}{c}1941-49 \\
8 \mathrm{yrs} / 3 \\
\text { mths }\end{array}$ & $\begin{array}{c}1941-65 \\
24 \text { yrs }\end{array}$ & $\begin{array}{c}1945-47 \\
2 \text { yrs }\end{array}$ & & $\begin{array}{c}1965-68 \\
3 \mathrm{yrs} / 1 \mathrm{mth}\end{array}$ & \begin{tabular}{|c|}
$1953-59$ \\
6 yrs/1 mth
\end{tabular} & & $\begin{array}{c}1957-60 \\
\text { 3yrs }\end{array}$ \\
\hline $\begin{array}{c}1972-75 \\
2 \text { yrs } / 11 \\
\text { mths }\end{array}$ & $\begin{array}{c}1976-88 \\
12 \mathrm{yrs} / 10 \\
\text { mths }\end{array}$ & $\begin{array}{c}1952-55 \\
2 \text { yrs/6 } \\
\text { mths }\end{array}$ & & $\begin{array}{c}1970-79 \\
9 \text { yrs } / 4.5 \\
\text { mths }\end{array}$ & \begin{tabular}{|c|}
$1971-74$ \\
3 yrs/1 mth
\end{tabular} & $\begin{array}{c}1972-82 \\
10 \text { yrs }\end{array}$ & $\begin{array}{c}1972-75 \\
3 y r s\end{array}$ \\
\hline $\begin{array}{c}1983-96 \\
13 \mathrm{yrs}\end{array}$ & & $\begin{array}{c}1982-90 \\
10 \text { yrs/6 } \\
\text { mths }\end{array}$ & $\begin{array}{c}1989-96 \\
6 \text { yrs/1 mth }\end{array}$ & $\begin{array}{c}1982-93 \\
11 \mathrm{yrs} / 1 \\
\mathrm{mth}\end{array}$ & $\begin{array}{c}1983-92 \\
10 \mathrm{yrs}\end{array}$ & $\begin{array}{c}1989-92 \\
3 \text { yrs }\end{array}$ & $\begin{array}{c}1984-90 \\
6 \text { yrs, } 3 \\
\text { mths }\end{array}$ \\
\hline $\begin{array}{l}2007- \\
1 \mathrm{mth}\end{array}$ & $\begin{array}{c}1995-2007 \\
12 \mathrm{yrs} / 10 \\
\text { mths }\end{array}$ & \begin{tabular}{|c|}
$1999-2007$ \\
$5 y r s / 3$ \\
mths
\end{tabular} & $\begin{array}{c}1998-2007 \\
7 \mathrm{yrs} / 6 \\
\text { mths }\end{array}$ & $\begin{array}{c}2001-07 \\
5 \text { yrs }\end{array}$ & $\begin{array}{c}2001-07 \\
4 \text { yrs/10 } \\
\text { mths }\end{array}$ & $\begin{array}{c}1998-2007 \\
6 \mathrm{yrs} / 6 \\
\text { mths }\end{array}$ & $\begin{array}{c}1999-2007 \\
8 \mathrm{yrs}\end{array}$ \\
\hline $\begin{array}{l}\text { TOTAL: } \\
35.58 \text { yrs. }\end{array}$ & 61.67 yrs. & 26.71 yrs. & 54.75 yrs. & 44.38 yrs. & 52.33 yrs. & 63.23 yrs. & 34.25 yrs. \\
\hline
\end{tabular}

Sources: Pre-1991 Australian figures based on data in C. Macintyre, Political Australia: A Handbook of Facts, Oxford University Press, Melbourne, 1991; pre-1996 New Zealand figures based on Francis Castles, Rolf Gerritsen, and Jack Vowles (eds), The Great Experiment: Labour Parties and Public Transformation in Australia and New Zealand Auckland: Auckland University Press, 1996, p. 5; subsequent figures from various public sources.

Considerable historical debate has surrounded why it took the NZLP until 1935 to win office. However, this debate has been confined to New Zealand historians, and their gaze has been similarly confined to New Zealand. Comparison with Australia allows us to ask a different question: why was the ALP able to achieve electoral success so much earlier than the NZLP? The answer in large part derives from the explanations for the earlier formation of the ALP, principally the earlier development of industry and an industrial working class in Australia. However, two other trends stand out as assisting the ALP develop an electoral base. First, the union movement which provided a major part of the support base for both parties 
enjoyed a significantly larger membership density in Australia after the first decade of the twentieth century. Furthermore, this union base had developed earlier in Australia, in the 1880s such that by 1890 membership density exceeded 20 per cent in the most populous and industrialised colonies of NSW and Victoria. These unions were largely decimated in the 1890s depression and employers' assaults which led to major strikes in that decade, but when unionism began to recover in the 1900s, it built on the habits and communities of association which had produced the earlier membership surge, and which contributed to labour's political base. ${ }^{54}$ When New Zealand unions recovered from defeat in 1890, their initial growth was based much more on the institutional support of the arbitration system; not until the Red Feds was a substantial part of the union movement firmly rooted in community. ${ }^{55}$

Secondly, the ALP was more successful than the NZLP in attracting a mixed social base in its early years. Labour MPs and prominent party members in both parties included a significant mixture of social backgrounds, including journalists, lawyers, and clergymen as well as manual workers and unionists. ${ }^{56}$ More importantly, however, the ALP tapped a major source of rural support through the AWU, which initially represented many small landholders as well as pastoral workers and delivered a substantial number of rural electorates in NSW and Queensland until the 1930s. ${ }^{57}$ It was also the AWU's adoption of American spelling forms which influenced the adoption of 'Labor' in the title of the ALP. Even afterwards, as late as the 1970s and 1980s, the ALP gained a significant number of rural seats, if not through the AWU..$^{58}$ The NZLP, however, received less rural support in its formative years because the farmers already enjoyed a political base in the Liberal Party, early NZLP land policies for leasehold repelled farmers, and rural unionism gained less traction than in Australia. Rural workers were inclined to vote alongside farmers, since they were 'peculiarly deferential and right-wing', and the early New Zealand Shearers Union was also tied to the Liberals. ${ }^{59}$

For several decades the accepted view originating with Robert Chapman in 1948 was that the NZLP finally won government in 1935 by gaining the support of small farmers and the urban middle class. ${ }^{60}$ Bruce Brown added that until the NZLP gained farmers' support it was disadvantaged by the country quota which gave rural electorates 28 per cent greater representation than they were entitled to on the basis of population: ${ }^{61}$ Chapman also argued that the three party system held back the NZLP from gaining office, on the grounds that middle-class protest votes regularly went to the opposing conservative party (either Reform or Liberal/ United $^{62}$ depending on who was in power) rather than to the NZLP. ${ }^{63}$

Miles Fairburn challenged this orthodoxy in 1985. He argued that the NZLP's difficulties over the 1920s can be attributed to the high incidence of blue-collar workers who either failed to vote or voted for the conservative parties, although he further acknowledged that had the NZLP won more middle-class support it would have secured more votes and seats. ${ }^{64}$. Brown also recognised the importance of 'working class Toryism', 65 for which Fairburn identified three reasons. Firstly, he noted the relatively high degree of geographic mobility, which peaked during and after World War I, the formative period of the NZLP. Fairburn argued that high rates of geographic mobility reduced workers' capacity for collective organisation. Secondly, Fairburn observed the spatial fragmentation of the working class produced by the relatively small scale of industry and urbanisation. Finally, Fairburn 
argued that the general desire of the working class to own property predisposed them towards non-Labour. ${ }^{66}$ Erik Olssen supported this claim stating that 'male workers in the handicraft sector ... were probably more likely to stay committed to the Liberals or even to vote for Reform' because of continued opportunities for becoming self-employed. ${ }^{67}$ Fairburn and Haslett's study of New Zealand workingclass conservatism in the ten largest provincial towns at 11 general elections, 1911-51 confirmed that the skilled working class initially had a much lower propensity to vote for the NZLP than the unskilled/ semiskilled working class. ${ }^{68}$ With data from the same study Steve McLeod also disputes Chapman's labelling of 'farmer' or 'rural' seats, maintaining that they were in fact dominated by manual workers, and that the NZLP's eventual victory in these electorates was a result of demographic change and urbanisation which increased their numerical importance in 'rural' seats. ${ }^{69}$

The NZLP, therefore, was predominantly an unskilled / semiskilled working-class party until the 1930s, based in the major urban areas and in a couple of exceptional rural seats such as the West Coast (with large populations of unionised miners and timber workers). ${ }^{70}$ By the 1930s the NZLP was able to gain the support of skilled workers in rural electorates and even some of the middle class. ${ }^{71}$ The change in fortunes for the NZLP was assisted by the ravages of the Great Depression, the collapse of the three party system (with unification of the United Liberal and Reform Parties in the 1930s), and Labour's alliance with the Ratana Maori candidates. ${ }^{72}$

After they became the mass working-class party in Australia and New Zealand respectively, the ALP and NZLP support base was remarkably similar for much of the twentieth century. Even the proportion of votes gained by each party was very similar in elections from 1945 to $1996,{ }^{73}$ when New Zealand adopted a different voting system: Mixed Member Proportional (MMP). However during the second half of the twentieth century the membership base of both parties declined significantly and changed in social composition. At its peak in 1954 ALP membership was 75,000, with affiliated unions representing 75 per cent of unionists, and 40 per cent of workers. At the end of the decade, after the 1955 split, the ALP had only 45,000 members, and this base continued to decline afterwards. ${ }^{74}$ A similar pattern occurred for the NZLP, with a major loss of members in the 1980s during the period of 'Rogernomics', although in 2007 the NZLP claimed that membership was growing again. ${ }^{75}$

In particular, blue-collar working-class membership and electoral support for both parties declined after the 1950s, and they increasingly attracted white-collar workers and professionals, particularly engaged in public sector services. Gustafson noted that manual workers declined from 84 per cent of NZLP membership in 1949 to 49 per cent in 1970, as white-collar workers increased from 16 to 51 per cent of the NZLP membership base. ${ }^{76}$ Similarly the percentage of Labour MPs who were employed in professional and semi-professional work increased from 18 per cent in 1935 to 73 per cent in $1984 .{ }^{77}$ In his study of occupations during party conferences in 1983 and 1988, Jack Vowles noted that 55 and 53 per cent respectively were employed in the public sector, whereas only 19 and 14 per cent respectively were manual workers. $^{78}$ In addition those Labour MPs previously employed as manual workers decreased from 27 per cent in 1935 to 5 per cent in $1984 .{ }^{79}$ This decline in manual working-class involvement in the NZLP exceeded the overall decline in blue-collar employment; the proportion of households with manual workers declined from 43 to 35 per cent from in 1967 to $1993 .^{80}$ In Australia the proportion of professional and 
white-collar membership virtually tripled between 1961 and 1981, to reach about a quarter, exceeding their proportion of the general workforce. ${ }^{81}$

Generally, changes in electoral support have followed the same trends identified for party membership, although not as drastically. Although such classifications are fraught with difficulties, it does seem that from the late 1980s the blue-collar working-class vote for the ALP declined, while the 'middle class' vote increased..$^{82}$ For some commentators these trends represented a 'middle-classing' of the parties, ${ }^{83}$ although it could also be argued that the composition of the working class itself had changed. Vowles also noted that class voting in New Zealand has declined. ${ }^{84}$

The change in composition and decline in membership for the ALP and NZLP was associated with broader social change and party-political difficulties. Social change included the decline in heavy industry, the growth in tertiary sector employment and the breakdown of traditional working-class communities. ${ }^{85}$ Falling trade union membership contributed to the decline in the support base for both parties, as well as indicating social change. In Australia union membership as a proportion of the workforce declined from a peak of 61 per cent in 1954 to 20 per cent in 2007, and in New Zealand union membership density declined from 60 per cent in 1945 to 17 per cent in 1999 (after which it began to increase very gradually). ${ }^{86}$

Transformation of the parties' membership base has increased the role of women, who are strongly represented in the white-collar workforce. Both parties enrolled female members from an early stage. The NSW Labor Party decided to do so at its first, all-male conference in 1892 prior to women gaining the suffrage in that or other Australian colonies, although it was a somewhat divisive issue at the time and female suffrage did not enter the platform until 1896. ${ }^{87}$ Women's groups such as the Auckland Women's Political League affiliated with the NZLP from the outset, ${ }^{88}$ reflecting the fact that the party's formation occurred 23 years after female suffrage was gained in New Zealand. In some Australian states the ALP established special structures for women's representation, such as the Women's Central Organising Committee from 1904 in NSW, and women's conferences; in 1929 Inter-state Labour Women's Conferences were organised and in 1930 a Labor Women's Interstate Executive was established. ${ }^{89}$ The NZLP had a Women's Representative elected to the central executive by conference, and women's conferences from 1927, but more importantly the radical women's groups incorporated into the party formed specific women's branches which sometimes had their representatives elected to the central executive. ${ }^{90}$ Nevertheless, both parties were male dominated for much of the twentieth century. Women rarely gained leadership positions in either party, or parliamentary seats. The parties were also influenced by the attitudes of male trade unionists, who often saw women as posing a threat to male jobs and organised to prevent it in the context of state arbitration systems which maintained lower wages for women. ${ }^{91}$

From the late 1970s new wave feminism, the campaign for equal pay and a Working Women's Charter exerted strong influence in the labour movements of both countries. From the 1980s women began to enter leadership positions in growing white-collar unions and in both parties. Senator Susan Ryan became the first ALP federal cabinet member in 1983-87. The number of female ALP caucus members grew, aided by the 1994 conference adoption of affirmative action, which committed the party to the endorsement of female candidates in at least 35 per cent of winnable seats at federal level from 2002, and similar measures at state level. In 1990 two 
female ALP state premiers emerged, Joan Kirner in Victoria and Carmen Lawrence in Western Australia, although both were appointed as caretakers for ALP governments seriously disabled by perceptions of economic mismanagement. ${ }^{92}$ Since 2001 the ALP deputy parliamentary leader also has been a woman. The NZLP established a Women's Advisory Council in 1970, succeeded by the Labour Women's Council in 1975 , to promote women members' view in the policy making process, and in 1978 a Women's Coordinator was appointed. Margaret Wilson was president of the NZLP in the mid-1980s. The New Zealand Labour government of 1984 included ten women, amongst them Ann Hercus, the first Minister of Women's Affairs, and Helen Clark, who became the first New Zealand party leader in 1993, and Prime Minister in 1999.93 Under a Clark-led government, all of the top jobs in New Zealand were occupied by women in 2005, including Speaker of Parliament, Governor-General and Chief Justice, and six were government ministers (of 25 from the NZLP in the coalition).

The change in party membership and electoral support for the ALP and NZLP has been paralleled by changes in party ideology and policy. It has been argued that the 'middle-classing' of ALP membership has led to changed policy priorities, including the dismantling of the traditional tenets of Labourism, which has further alienated traditional blue-collar voters and potential members. Similar tendencies have been noted in the NZLP from the 1970s and particularly the 1980s.

\section{Ideology and Policy}

Ideologically the ALP and the NZLP were principally influenced by a combination of socialism and liberalism with a strong connection to trade unionism. ${ }^{94}$ Both parties inherited traditions of liberal reform. ${ }^{95}$ For example, the system of compulsory state arbitration, to which the labour movement in both countries became committed, was initiated by liberals: William Pember Reeves in New Zealand in 1894, and Charles Kingston, Bernard Wise and Alfred Deacon in Australia between 1901 and $1904 .{ }^{96}$ It was a similar story with the beginnings of state welfare in the old age pension, introduced in New Zealand in 1898, and in NSW and Victoria in 1900 and the Commonwealth of Australia in $1908,{ }^{97}$ and with factory legislation, which during the 1890s was improved in New Zealand and Victoria and introduced in NSW, South Australia and Queensland. ${ }^{98}$ Macintyre and Burgmann argued that the mobilisation of a pre-industrial working class in unions and the ALP inevitably resulted in its acceptance of liberal ideology, ${ }^{99}$ as Saville had argued for Britain ${ }^{100}$, and the situation was similar for New Zealand. However, there is also no doubt of the early influence of socialism in the ALP in the 1890s (particularly NSW and Queensland), ${ }^{101}$ and in the NZLP and its various predecessors which came together in 1916. The ALP was predominantly influenced by state socialism, whereas the NZLP was more influenced by Red Fed militant socialists who set syndicalism aside to form the party. ${ }^{102}$ The early NZLP's industrial policy, which combined state ownership with union membership also has been characterised as akin to British guild socialism. ${ }^{103}$ Furthermore, as parties of the left, at least initially, the ALP and NZLP attracted various other forms of radicalism. The followers of Henry George exerted some influence in the Australian and New Zealand labour movements in the 1890s, especially in NSW, in the form of the 'single tax' or land nationalisation policies. ${ }^{104}$ In the 1930s, Douglas Credit was influential on the left of the NZLP, although its impact in the ALP was more short-lived. ${ }^{105}$ 
The combination of elements of socialism and liberalism with trade unionism produced Labourism, the dominant ideological influence within the ALP and NZLP, shared also with the British Labour Party. The term 'Labourism' is employed here to denote this particular ideological combination, rather than in the sense criticised by Terry Irving and others as implying a less authentic non-Marxist socialism. ${ }^{106}$ Writing in the New Zealand context, Gustafson claimed that Labourism involves 'the acceptance of capitalism but on conditions which recognise trade unions as the corporate pressure group representing the workers in a state-controlled, tripartite system of collective bargaining' ${ }^{107}$ Jim Hagan echoed this definition for the ALP when he claimed that Labourism assumed that 'the capitalist state could be managed to the advantage of the working class by a combination of a strong trade union movement with a parliamentary Labor Party'. ${ }^{108}$ John A. Lee summed up the NZLP's position claiming that it 'was gathering momentum on a new road, not towards social revolution, but towards a tamed humane state capitalism' ${ }^{109}$. In Australia, the ALP's task has been described similarly, as 'civilising capitalism'. ${ }^{110}$ This was the Socialism Without Doctrine described by Albert Métin in $1901^{111}$ after his visit to the antipodes to investigate the 'social laboratories of the world' (although in the New Zealand case he was mainly referring to the Lib-Labism of the Liberal Party). Both parties have emphasised a moderate parliamentary strategy for incremental reform working through the state apparatus that was assumed to be neutral. However as noted by Irving, this did not deny the working-class-based nature of Labo(u)r politics as claimed by the New Left. ${ }^{112}$ Notwithstanding their Marxist ideologies, the European social democratic parties of the Second International did not differ significantly in political practice from the early ALP and NZLP.

The programmatic expression of Labourism for the ALP and NZLP, however, was unique. Each focused on defence of workers as wage earners, as a result of the influence of trade unions and the emphasis on minimum wages and prevention of 'sweating' in the political culture of colonial liberalism at the end of the nineteenth century and beginning of the twentieth, a formative period for the labour movement in each country. In policy terms this led to protection of domestic manufacturing industry and the defence and extension of compulsory arbitration along with other industrial legislation. Protection of domestic manufacturing, with high tariff walls in Australia and subsidies and import restrictions in New Zealand, ensured employment in this strongly unionised sector, whilst more capital intensive, productive primary sectors successfully competed in international markets to earn overseas income. Protection of domestic industry enabled employers also to pay a 'living wage', a link made politically explicit in the 'new protection' of the early Commonwealth of Australia. Arbitration structures implemented the 'living wage' through centralised wage determination systems which uniquely adopted policies that profitability was not to be the sole determinant of wages, although this had not been the original intention of the liberal instigators of these structures. At the same time, state arbitration systems forced union recognition by employers who had denied this in the major strikes leading to the formation of the labour parties. The systems privileged unions as representatives of workers in their deliberations, and in New Zealand with compulsory unionism from 1936. In turn, a strong union movement helped to sustain labour parties which, through legislation and expansion of state employment, helped maintain industrial frameworks favourable to unions and working conditions. ${ }^{113}$ 
The strategy typified Labourism, although, as we have seen, much of it had been initiated by liberals. In Australia, this 'new protection' policy which brought the support of domestic manufacturers and liberals to labour, has been called a 'national settlement' at the beginning of the twentieth century. It attracted a similar consensus in New Zealand, which has been called a 'settler contract'. ${ }^{114}$ This consensus persisted in both countries for much of the twentieth century, within a Keynesian policy framework for maintaining full employment after the 1930s depression. ${ }^{115}$

Frank Castles has characterised the Labourist public policy consensus adopted in Australia and New Zealand as a strategy of 'domestic defence' based on 'wage earners' welfare states'. ${ }^{116}$ Social justice within this strategy was based on wageearning status rather than citizenship, thus retarding the development of a broader universal welfarism, and privileging male trade unionists because the definition of a 'living wage' excluded women from its ambit by taking a male family breadwinner as its basis. Castles' argument is strongest in the case of the ALP, although even here it may be exaggerated. The ALP did exhibit an early interest in broader welfare, including strong support for invalid and old age pensions, and when in power nationally introduced a maternity allowance in 1912, in the context of fears of being overrun by Asians unless the population was increased. ${ }^{117}$ In 1897 the NSW party also adopted a plank for a free state health scheme, ${ }^{118}$ but little else appeared in early ALP platforms or legislative priorities when in power. Welfare became more of an issue after World War II, in Australia and all developed countries, within a broader context of the ascendancy of Keynesian approaches to public policy. Furthermore, the ALP was constrained in practice by limited periods of national office, the budgetary constraints of the depression in 1929-32 when the Scullin ALP government was in national office and welfare was needed most, and by the constraints of the federal system, which limited the powers of the national government in social policy until the referendum of 1946, but also limited the resources of the state governments. ${ }^{119}$

Castles' characterisation of the wage earners' welfare strategy is much weaker in the case of the NZLP. When elected to government in 1935 the NZLP created what was arguably the capitalist world's first universal welfare state. The timing of achievement of government largely explains the NZLP's greater emphasis on universal welfare policies, given the recent experience of the hardships of the 1930s depression. Under the leadership of Michael Joseph Savage the first Labour government implemented polices for a largely free national health scheme, and income support through universal pensions and family benefits, in addition to more wage earner oriented industrial measures which characterised state ALP government policies: a minimum hourly wage, a 40-hour working week and compulsory unionism. ${ }^{120}$ The third NZLP government of 1972-75 also implemented a raft of social legislation, including comprehensive accident compensation and a benefit scheme for single-parent families. ${ }^{121}$ By that time the ALP, under Gough Whitlam, also enacted a similar expansion of social legislation.

A major distinction between the parties was over racial policy, particularly in relation to indigenous people whom each of the settler dominated societies had dispossessed. For the ALP a 'white Australia' policy was a critical third pillar for the national settlement of new protection. Just as domestic manufacturers were to be protected from cheap overseas competition, so too were workers protected from cheap wage competition in the form of Asian immigrant labour, by restrictive 
immigration policy. 'White Australia' was based on a fear of cheap Asian labour, but also on an overt racism that was shared generally throughout colonial European society in the antipodes, and therefore, increased the ALP's appeal to a broader electorate than just workers. 'The cultivation of an Australian sentiment based upon the maintenance of racial purity' became the first federal objective of the ALP in 1905 , before any mention of social justice. ${ }^{122}$

The New Zealand labour movement, and wider European society, were equally as committed to a 'white New Zealand'. In 1899 the Liberals effectively restricted nonwhite immigration through poll taxes and tonnage ratios on ships, and subsequently the arbitration court banned Asian workers from membership of unions whilst also giving unionists preferential access to jobs. The IPLL, the first NZLP and the ULP all demanded white New Zealand in their platforms. However, because of the success of the 1899 legislation, and the lack of a large scale non-white and nonindigenous workforce such as the Melanesian 'Kanakas' in Queensland, the issue was less defining for the post 1916 NZLP than it was for the ALP, even if rank and file hostility to Asian immigration was similar. A more important distinction lay in the implication for indigenous peoples. 'White Australia' also disenfranchised many Aborigines as citizens, whereas 'white New Zealand' was outwardly directed against Asians only. The Treaty of Waitangi conferred a different status upon the New Zealand Maori, as British subjects. In the process of Maori dispossession and the wars of 1845-47, 1860-61 and 1863-76, the British considered the Maori as 'worthy foes', and theoretically they gained equal status with the white settlers, the Pakeha, effectively as 'honorary whites'. This proved to be one of the major stumbling blocks for New Zealand joining the Australian federation in $1901 .{ }^{123}$

Alongside domestic defence through the wage earner welfare state, Labourism as an ideology also found a cogent expression in shared policies to extend public ownership and the social and economic role of the state. ${ }^{124}$ This attracted and was influenced by the various socialist groups that existed in both parties from the outset. However, the state socialism of the ALP and NZLP never became a wholehearted program for the complete displacement of capitalism. The boundaries of state socialism were regularly contested in both parties, especially the ALP, but always contained within the pragmatic reformism that characterised Labourist political practice.

In Australia the original platform drawn up by the Queensland party in 1890 called for the complete nationalisation of industry, but this was rejected by affiliated unions in favour of a more moderate program of political and industrial reform. In 1897 the NSW party adopted 'nationalisation of the land and the whole means of production, distribution and exchange' as a plank, but this was diluted to the 'collective ownership of monopolies' in 1905, which was also adopted federally. ${ }^{125}$ In 1921 the federal ALP's objective became 'the socialisation of industry, production and exchange'. ${ }^{126}$ The methods by which this would be achieved included not only 'nationalisation of banking and all principal industries', but also 'the municipalisation of such services as can best be operated in limited areas'. However, in 1921 the Blackburn Declaration was adopted to qualify this objective: collective ownership would only be 'to whatever extent may be necessary' for 'preventing exploitation'. By 1957, after the gradual consolidation of the objective, it became: 'The democratic socialisation of Industry, Production, Distribution and Exchange - to the extent 
necessary to eliminate exploitation and other anti-social features in those fields...'. In 1916 the NZLP adopted the SDP objective for 'the socialization of the means of production, distribution and exchange'. This objective remained until its deletion in 1951, although in 1927 land nationalisation was deleted from NZLP policy in an attempt to woo farmers. ${ }^{127}$

For both parties the commitment to public ownership often represented more of a symbolic rallying point than a concrete proposal for social reform. Nonetheless, early ALP governments did create state enterprises, mainly at the state level, for example, abattoirs, brickworks, timber yards, quarries, and insurance companies, and they expanded the largest enterprises of all, the state railway corporations. ${ }^{128} \mathrm{At}$ the national level the Commonwealth Bank was formed in $1912 .{ }^{129}$ Both parties were particularly concerned with the banking system as the citadel of capitalism. This was confirmed by the experiences of the 1930s depression when banks supported orthodox financial policies which made it impossible for the Scullin national ALP government and the Lang NSW ALP government to finance traditional wage earner welfarism. ${ }^{130}$ Soon after it came to power the NZLP nationalised the Reserve Bank in 1936, and the main trading bank, the Bank of New Zealand, in 1945. ${ }^{131}$ The ALP attempted to nationalise all banks in 1947-54, although the High Court and Privy Council ultimately ruled this unconstitutional. ${ }^{132}$ The 1940s marked the highpoint of Labourism as public ownership in both countries. The NZLP established state monopolies in broadcasting, domestic airways, the linen flax industry, coal mines gradually came under state ownership, and the state became a major provider of housing. ${ }^{133}$ Similarly, in Australia state government housing expanded and a national ALP government nationalised the international airline Qantas Empire Airways by buying up all shares. It also created a domestic airline, Trans-Australian Airlines (TAA), although the High Court rejected its attempt to nationalise Australian National Airways (ANA). ${ }^{134}$ This and the ruling over banks seemingly prevented further efforts for nationalisation, at least by the federal government, and the issue never arose again in ALP policy. None of these measures was intrinsically part of a wider strategy of radical social change, although many Labo(u)r supporters would have thought they were. Conservative governments accepted most of these measures in the post-war Keynesian consensus prevailing in New Zealand and Australia until the 1980s. ${ }^{135}$

Labourism had opponents on the Left. In Australia the syndicalist One Big Union Movement (OBU) after World War I and Communist Party of Australia (CPA) in the 1930s to 1940s mounted substantial challenges to the Labourist hegemony in the labour movement. ${ }^{136}$ In New Zealand, as we have noted, syndicalist influence in the labour movement peaked in the Red Feds immediately prior to the formation of the NZLP. The New Zealand Communist Party was never in the position to surpass the NZLP. Communist Party members were expelled from the ALP in 1924 and the NZLP in $1926 .{ }^{137}$ In neither country did Communists effectively challenge the Labo(u) r parties' electoral strategy, but instead worked principally through influence in the unions. We may, therefore, speak of a Labourist hegemony for much of the twentieth century in both countries.

Nevertheless, Labourism has been a contested concept especially in the ALP. During the early 1930s, for example, the NSW branch of the ALP split from the federal ALP over policy responses to the depression, with the NSW ALP state government 
adopting a more radical Labourist response than the federal ALP government's adoption of the principles of 'sound finance', which involved major reductions in government expenditure. ${ }^{138}$ Across the Tasman, the NZLP observed the weakness of the federal government with alarm, and was repelled by what it considered the 'Tammany Hall' tactics of the NSW ALP; the NZLP's relations with the British Labour Party were closer as a result. ${ }^{139}$

The ALP split of 1955 threatened its institutional and electoral viability. ${ }^{140}$ Its origins lay in the formation of Industrial Groups within the ALP and unions from 1945 to fight the influence of communism. The Groups became dominated by the Catholic Social Studies Movement, whose implacable opposition to communism increasingly meant a total alignment with US foreign policy, and opposition to ALP leftists who allied with Communists in the unions. From the late 1940s to 1952 the Groupers succeeded in completely replacing CPA or left leaderships in some key unions, but a number of ALP politicians and union officials, including some from the right, felt threatened by the ambition of the Groups. In October 1954 the ALP's federal leader, H.V. Evatt, called for the Groups' dissolution. The subsequent convulsions led to the split of 1955, when the Groups were officially disbanded, major 'Groupers' were expelled from the ALP, and the rightist Democratic Labor Party (DLP) was formed. The impact of the split had a debilitating effect on the ALP particularly in Victoria, where the ALP lost state government in Victoria in 1955 as a result of expulsions of Parliamentary Labor Party members. The Groupers were also involved in a split in the Queensland parliamentary party and loss of government in 1957. ${ }^{141}$ At the federal level, and in the state of Victoria, the existence of the DLP was a major factor preventing the election of ALP governments for 23 and 27 years respectively. The NZLP, however, avoided such major convulsions during the Cold War, especially due to the smaller Irish Catholic influence.

The 1950s convulsions created the basis of the ALP's main factions, left, centre and right, although there had always been factional divisions in the party with various names depending on the state. By the 1990s 'Centre Unity' denoted the right, which has a stronghold in NSW, 'Centre Left' denoted a small centre group, and 'Socialist Left' denoted the left, with a particular stronghold in Victoria, although the older term 'Steering Committee' was still used in NSW. From the 1980s they became increasingly formalised and most members of the Parliamentary Labor Parties are now members of a faction. Negotiations between faction leaders have increasingly provided the basis for decision-making processes over distribution of cabinet and party officers' positions, and determination of policy, thus avoiding the damaging conflict previously seen by the public in caucus and conferences. ${ }^{142}$ However, the factions have become less involved with ideology as greater consensus develops in the ALP. A former Cabinet Minister in the 1980s and 1990s, Neal Blewett, described the caucus factions as 'clans or tribes, grouped around factional leaders, with long histories of internal political cooperation, rather than ideological groupings'. Their leaders 'had to pay obeisance to certain shibboleths ... But provided the leaders could secure offices and perks for members of the tribe, the tribe would acquiesce in most ideological accommodations reached by the leaders of the factions'. ${ }^{143}$ The NZLP's left and right factions have not become as formalised as the ALP versions.

During the last quarter of the twentieth century the traditional policy basis of Labourist thinking in both countries came under attack and both parties effectively abandoned the commitment to public ownership. ${ }^{144}$ In the early 1970s the Whitlam 
ALP government abandoned the 'white Australia' policy, one of the key planks of the Labourist consensus of the early 1900s. By the late 1970s many from the right of the ALP questioned the continuing relevance of a socialist objective, seeing it as an electoral liability, but a 1981 special national conference retained it intact. ${ }^{145}$ Nevertheless, from 1983 to 1996 ALP governments adopted the mantras of economic rationalism in engineering economic restructuring, within a corporatist framework of the Prices and Incomes Accord with the Australian Council of Trade Unions. ALP governments deregulated much of the economy and at federal and state levels privatised a number of statutory corporations and authorities. Ironically, the ALP itself took the major role in dismantling the Labourist consensus of the beginning of the century by abandoning protection for Australian industry and weakening the system of compulsory state arbitration in favour of enterprise bargaining. ${ }^{146}$

In government, the NZLP dramatically abandoned Labourism in the 1980s. In response to rising oil prices, economic stagflation, growing unemployment and a balance of payments deficit the fourth Labour government under the leadership of David Lange implemented measures, which resembled the 'New Right' agenda of Thatcher's Conservative government in Britain. ${ }^{147}$ These policies, which became known as 'Rogernomics', after their architect, Minister of Finance Roger Douglas, included economic deregulation, the corporatisation and privatisation of state-owned assets and the removal of subsidies and tariffs. However, as with the ALP, although the NZLP reformed the arbitration system to encourage enterprise bargaining, the structure itself remained intact until a conservative government abolished it. These neo-liberal policies severely divided the NZLP in the late 1980s, leading to the resignation of Prime Minister David Lange and the NZLP's eventual electoral defeat in 1990. In reaction to Labour's neo-liberalism, a New Labour Party was created in 1990, which espoused more traditional Labourist ideology. After the humiliating defeat of the 1990 election, the NZLP under the leadership of Helen Clark claimed it had returned to the centre-left of the political spectrum. During the late 1990s Labour leaders have espoused the politics of the 'Third Way', a vague set of ideas attracting the interest of labour and social democratic parties in Europe and elsewhere, and most prominently advocated by former British Prime Minister Tony Blair. The Third Way accepts free market capitalism, but tempers it with social justice aspects of Labourist and social democracy ideology. Since being elected in 1999 the fifth Labour government has implemented the Third Way model by delicately balancing the goals of limited state intervention and the retention of essential features of free market reform: social liberalism. ${ }^{148}$ However, the extensive growth of public sector employment, increased expenditure in welfare areas such as health and education, and attempts to recollectivise industrial relations with the Employment Relations Act 2000, are remarkably like traditional Labourist strategies. ${ }^{149}$ After more than a decade in opposition at the national level, the ALP has also embraced Third Way style policies, although where the NZLP tends to look towards the social democratic traditions of Scandinavia for inspiration, the ALP is more likely to look towards the United States Democrats.

\section{Conclusions and Comparative Perspectives}

The ALP and NZLP have been sufficiently similar in their political trajectories, support base and Labourist ideology to be seen as a characteristically antipodean 
phenomenon, although they share many of these aspects with the BLP too. The main distinction between the antipodean parties and the BLP has been in the programmatic expression of Labourist ideology in a 'wage earner welfare' strategy. In this and other ways the direct influence between the ALP and the NZLP is also notable, particularly in commitment to state arbitration systems.

Notwithstanding these similarities, the differences between the parties are significant in terms of political trajectory, structure and policy. The timing of the NZLP's consolidation was significantly later than the ALP. The ALP's federal structure and activities also differ from the more unitary NZLP structure, and have provided greater scope for the more frequent divisive splits and factionalism experienced in the ALP. In terms of policy, the attitude towards indigenous people has been remarkably dissimilar, and the NZLP led the way internationally in adopting an extensive state welfare policy.

How do we explain these intersections? The similarities between the parties in terms of ideology, strategy, support base and electoral record, can be accounted for principally by structure rather than agency. The commonalities derive from shared cultural heritage from Britain, their shared origins as globally isolated but proximate settler societies, and similar small, resource and agriculturally based economies.

The differences are more complex to account for. The structure of the state in itself explains the different structures of the parties, federal versus unitary, as well as a good deal of differing political experience. Structure again is important in explaining the different timing of party consolidation. The larger scale of industry and its faster development in Australia provided an earlier working-class support base for the ALP. Absence of serious political rivals for attracting small farmers' support also assisted the ALP originally, in ways not possible for the NZLP. The timing of party consolidation itself, and particularly the achievement of government, also explain important policy differences. When the ALP was established in the 1890s, race was a far more important issue in all of the antipodean colonies as they faced independence, than later when the NZLP was consolidated. To some extent this explains the greater emphasis on race in the early ALP. We also have noted the impact of the 1930s depression on the NZLP's greater emphasis on universal welfare policies when it came to power in 1935. Even within the broad shared commitment to a labourist strategy, there was substantial scope for different policy emphases.

Ray Markey is Professor of Employment Relations, Associate Dean Research in the Business School, and Director of the New Zealand Work and Labour Market Institute at Auckland University of Technology. He has a long interest in research in the Australian labour movement, as well as international comparative labour history and contemporary employment relations.

<ray.markey@aut.ac.nz> 


\section{Endnotes}

* I acknowledge the constructive comments of two anonymous referees and Kerry Taylor on earlier drafts of this article.

1. A. Parkin, 'Party organisation and machine politics: the ALP in perspective', in A. Parkin and J. Warhurst (eds), Machine Politics in the Australian Labor Party, Allen and Unwin, Sydney, 1983, pp. 22-23; J. Warhurst, 'One party or eight? The State and Territory Labor Parties', in Parkin and Warhurst, Machine Politics in the ALP, pp. 257-58, 263-65; H. Roth, Trade Unions in New Zealand. Past and Present, Reed Education, Wellington, 1973, pp. 154-58, 160-66; R. Milne, Political Parties in New Zealand, Oxford University Press, Oxford, 1966, pp. 101-14, 181-86, 213-15, 224-26.

2. L. James and R. Markey, 'Class and labour: the British Labour Party and the Australian Labor Party compared', Labour History, no. 90, May 2006, pp. 23-42.

3. A. Grassby and S. Ordonez, The Man Time Forgot. The Life and Times of John Christian Watson, Australia's First Labor Prime Minister, Pluto Press, Sydney, 1999.

4. P. O'Farrell, Harry Holland. Militant socialist, Australian National University Press, Canberra, 1964.

5. J. Bennett, "Rats and Revolutionaries": The Labour Movement in Australia and New Zealand 1880-1940, University of Otago Press, Dunedin, 2004, pp. 150-52; B. Gustafson, From the Cradle to the Grave: A Biography of Michael Joseph Savage, Reed Methuen, Auckland, 1986.

6. Bennett, 'Rats and Revolutionaries', pp. 59-60; R. Davis, 'New Zealand Liberalism and Tasmanian Labor, 1891-1916', Labour History, no. 21, November 1971, pp. 24-35.

7. Bennett, 'Rats and Revolutionaries', pp. 29-38, 64-65; E. Olssen, The Red Feds. Revolutionary Industrial Unionism and the New Zealand Federation of Labour, 1908-1913, Oxford University Press, Auckland, 1988; D. Crowley, 'An outline history of the New Zealand labour movement, 1894-913', Historical Studies Australia and New Zealand, vol. 4, no. 16, May 1951, p. 368.

8. Bennett, 'Rats and Revolutionaries', pp. 57-60; R. Mitchell, 'State systems of conciliation and arbitration: the legal origins of the Australasian model', in S. Macintyre and R. Mitchell (eds), Foundations of Arbitration: The Origins and Effects of State Compulsory Arbitration 1890-1914, Oxford University Press, Melbourne, 1989, pp. 82-89, 93-98; R. Mitchell and E. Stern, 'The compulsory arbitration model of industrial dispute settlement: and outline of legal developments', in Macintyre and Mitchell (eds), Foundations of Arbitration, pp. 106-10; S. Goldfinch and P. Mein Smith, 'Compulsory arbitration and the Australasian model of state development: policy transfer, learning, and innovation', Journal of Policy History, vol. 18, no. 4, 2006, pp.427-39.

9. B. Gustafson, Labour's Path to Political Independence, Auckland University Press, Auckland, 1980, pp. 26, 55; R. Gollan, Radical and Working Class Politics: A Study of Eastern Australia 1850-1910, Melbourne University Press, Melbourne, 1966 (originally published 1960), pp. 105-6, 121-2; B. Scates, A New Australia: Citizenship, Radicalism and the First Republic, Cambridge University Press, Melbourne, 1997, ch. 2. Lane was editor of the Boomerang and the Worker in Brisbane, but his writings were also syndicated to the Australian Workman in Sydney.

10. Bennett, 'Rats and Revolutionaries', pp. 32-33.

11. The various state contributions each provide short biographical of early Labor members in D. Murphy (ed.), Labor in Politics: The State Labor Parties in Australia, 1880-1920, University of Queensland Press, St. Lucia, 1975. Also T. Roydhouse and H. Taperell, The Labour Party in NSW: A History of its Formation and Legislative Career, Dunlop, Sydney, 1892, pp. 22-51; Gustafson, Labour's Path to Political Independence, pp. 153-69.

12. Goldfinch and Mein Smith, 'Compulsory arbitration and the Australasian model of state development', pp. 421-22; A. Wells, Constructing Capitalism: An Economic History of Eastern Australia, 1788-1901, Allen and Unwin, Sydney, 1989, pp. 104-10.

13. Bennett, 'Rats and Revolutionaries', pp. 53, 159-60; H. Irving, To Constitute a Nation: A Cultural History of Australia's Constitution, Cambridge University Press, Melbourne,1997, pp. 66-67, K. Sinclair, 'Why New Zealanders are not Australians: New Zealanders and the Australian federation movement, 1881-1901', in K. Sinclair (ed.), Tasman Relations: New Zealand and Australia, 1788-1988, Auckland University Press, Auckland, 1988.

14. R. Markey, 'Australia', in M. van der Linden and J. Rojahn (eds), The Formation of Labour Movements 1870-1914: An International Perspective, vol. 2, Brill, Leiden, 1990, pp. 585-86; E. Olssen, 'New Zealand', in van der Linden and Rojahn, The Formation of Labour Movements, p. 610; G. Bolton, The Oxford History of Australia, vol. 5, 1942-1988: The Middle Way, Oxford University Press, Melbourne, 1990, pp. 39, 190.

15. M. King, The Penguin History of New Zealand, Penguin, Auckland, 2004, p. 282; F. Farrell, 'A laboratory of social reform: international literature dealing with the rise of the ALP', in Traditions for Reform in NSW: Labor History Essays, Pluto Press, Sydney, pp. 1-16; S. Macintyre, A Concise History of Australia, Cambridge University Press, Melbourne, 1999, pp. 151-52.

16. James and Markey, 'Class and labour: The British Labour Party and the Australian Labor Party compared', p. 27.

17. M. Mackerras and I. McAllister, 'Compulsory voting, party stability and electoral advantage in Australia', Electoral Studies, no. 18, 1999, pp. 227-29.

18. R. McMullin, The Light on the Hill: The Australian Labor Party, 1891-1991, Oxford University Press, Melbourne, 1991, pp. 289, 293, 295, 297, 402; P. Kelly, The End of Certainty. The Story of the 1980s, Allen and Unwin, Sydney, 1992, ch. 28. 
19. M. King, The Penguin History of New Zealand, Penguin Books, Auckland, 2003, p. 423.

20. M. Sexton, The Illusions of Power: The Fate of a Reform Government, Allen and Unwin, Sydney, 1979, pp. 75-77, 125-33.

21. J. Moss, Sound of Trumpets: History of the Labour Movement in South Australia, Wakefield Press, Netley, 1985, pp. 386, 388; D. Murphy, 'Abolition of the Legislative Council', in D. Murphy, R. Joyce, C. Hughes (eds), Labor in Power: The Labor Party and Governments in Queensland 1915-57, University of Queensland Press, St Lucia, 1980, pp. 95-116; J. Hagan and K. Turner, A History of the Labor Party in NSW 1891-1991, Longman Cheshire, Melbourne, 1991, pp. 98-105, 129-32, 17576, 187, 240; A. Shamsullah, 'Politics in Victoria: parliament, cabinet and the political parties', in M. Considine and B. Costar (eds), Trials in Power: Cain, Kirner and Victoria 1982-1992, Melbourne University Press, Melbourne, 1992, pp. 18-19; B. Costar, 'Constitutional change', in Considine and Costar, Trials in Power, pp. 204-206; R. Markey, The Making of the Labor Party in NSW, 1880-1900, NSW University Press, Kensington, 1988, pp. 203-204; H. Radi, 'Lang's legislative councillors', in H. Radi and P. Spearritt (eds), Jack Lang, Hale \& Iremonger, Sydney, 1977, pp. 99-118; E. Chaples, 'Wran in government: 1976-81', in E. Chaples, H. Nelson and K. Turner (eds), The Wran Model: Electoral Politics in NSW 1981 and 1984, Oxford University Press, Melbourne, 1985, pp. 43-44.

22. King, The Penguin History of New Zealand, pp. 492-93; A. McRobie, 'Elections and the electoral system', in R. Miller (ed.), New Zealand Government and Politics, $3^{\text {rd }}$ edn, Oxford University Press, Auckland, 2003, pp. 123-32.

23. Britain ranked second in terms of union membership at 22 per cent. Figure for Australia is based on Commonwealth Bureau of Census and Statistics, Labour and Industrial Branch Report No. 2, Trade Unions, Unemployment, Wages, Prices and Cost of Living in Australia, 1891-1912, 1913, and has been corrected from 25 per cent cited by Erik Olssen, 'The origins of the Labour Party: a reconsideration,' New Zealand Journal of History, vol. 21, no. 1, April 1987, p. 82.

24. See various contributions in Murphy, Labor in Politics; Gollan, Radical and Working Class Politics, ch. 8; F. Bongiorno, The People's Party: Victorian Labor and the Radical Tradition, 1875-1914, Melbourne University Press, Melbourne, 1996, pp. 25-6, 31-37; R. Fitzgerald and H. Thornton, Labor in Queensland From the 1880s to 1988, University of Queensland Press, St Lucia, 1989, pp. 1-10; J. Fowler, 'The 1890s turning point in Queensland history?', in D. Murphy, R. Joyce and C. Hughes (eds), Prelude to Power: The Rise of the Labour Party in Queensland, 1885-1915, Jacaranda Press, Milton, 1970, pp. 45-55; Markey, Making of the Labor Party in NSW, pp. 158-62, 171-80; Moss, Sound of Trumpets, pp. 147-68; N.B, Nairn, Civilising Capitalism: The Labor Movement in NSW 1870-1900, ANU Press, Canberra, 1973, pp. 20-64.

25. M. Nolan (ed.), Revolution. The 1913 Great Strike in New Zealand, Canterbury University Press in association with the Trade Union History Project, Christchurch, 2005, especially contributions by Nolan, Olsen and Miles Fairburn; Olssen, 'Origins of the Labour Party', pp. 79-96; E. Olssen and L. Richardson, 'The New Zealand labour movement, 1880-1920', in E. Fry (ed.), Common Cause: Essays in Australian and New Zealand Labour History, Allen and Unwin, Sydney, 1986, pp. 12-15; Olssen, The Red Feds, pp. 163-223; J. Vowles, 'Ideology and the formation of the New Zealand Labour Party', New Zealand Journal of History, vol. 16, no. 1, April 1982, pp. 39-55; B. Brown, The Rise of New Zealand Labour: A History of the New Zealand Labour Party from 1916 to 1940, Price Milburn, 1962, pp. 89-94.

26. P. O'Farrell, 'The formation of the New Zealand Labour Party', Historical Studies Australia and New Zealand, vol. 10, no. 38, May 1962, pp. 190-202.

27. James and Markey, The British Labour Party and the Australian Labor Party compared', p. 26; Markey, 'Australia', pp. 596-602; Markey, Making of the Labor Party in NSW, pp. 171-90; Murphy, 'Queensland', pp. 127-76; J. Dalton, 'An interpretative survey: the Queensland labour movement', in Murphy et al., Prelude to Power, pp. 9-22; J. Rickard, Class and Politics: NSW, Victoria and the Early Commonwealth, 1890-1910, ANU Press, Canberra, 1976, ch. 6.

28. Brown, Rise of New Zealand Labour, pp. 2-3; Bennett, 'Rats and Revolutionaries', p. 39; K. Sinclair, A History of New Zealand, Penguin, Ringwood, 1973 reprint of 1969 revised edn. (originally published 1959), pp. 172-88; King, The Penguin History of New Zealand, pp. 260-78.

29. Bongiorno, The People's Party; Rickard, Class and Politics, pp. 42-52; H. McQueen, 'Victoria', in Murphy, Labor in Politics, pp. 291-340; B. Dickey, 'South Australia', in Murphy, Labor in Politics, pp. 229-65; Moss, Sound of Trumpets, pp. 204-13.

30. Gollan, Radical and Working Class Politics, pp. 135-50; Markey, 'Australia', pp. 596-602; Markey, Making of the Labor Party in NSW, pp. 171-90; Murphy, 'Queensland', pp. 127-76; Dalton, 'An interpretative survey: the Queensland labour movement', pp. 9-22; Rickard, Class and Politics, ch. 7.

31. Brown, Rise of New Zealand Labour, p. 6.

32. Bennett, 'Rats and Revolutionaries', p. 66.

33. Olssen, 'Origins of the Labour Party', p. 84.

34. Brown, Rise of New Zealand Labour, pp. 4-5; Gustafson, Labour's Path to Political Independence, pp. 17-18, Olssen, 'Origins of the Labour Party', p. 86.

35. Gustafson, Labour's Path to Political Independence, p. 24.

36. Brown, Rise of New Zealand Labour, p. 7.

37. Gustafson, Labour's Path to Political Independence, pp. 30-1; Brown, Rise of New Zealand Labour, p. 8; Olssen, The Red Feds. 
38. Gustafson, Labour's Path to Political Independence, p. 40; Olssen, 'Origins of the Labour Party', p. 86.

39. Markey, Making of the Labor Party in NSW, pp. 179-90; R. Markey, In Case of Oppression: The Life and Times of the Labor Council of NSW, Pluto Press, Sydney, 1994, pp. 164-74, 195-98, 236-41.

40. McMullin, Light on the Hill, pp. 92-121; Hagan and Turner, History of the Labor Party in NSW, pp. 106-15.

41. Gustafson, Labour's Path to Political Independence, pp. 105, 108-19; O'Farrell, 'Formation of the New Zealand Labour Party', pp. 198-99; Vowles, 'Ideology and the formation of the New Zealand Labour Party, p. 46.

42. E. Hobsbawm, 'The making of the working class, 1870-1914', in E. Hobsbawm, Worlds of Labour: Further Studies in the History of Labour, Weidenfeld and Nicholson, London, 1984, pp. 194-213; H. Drucker, Doctrine and Ethos in the Labour Party, Allen and Unwin, London, 1979, p. 25; James and Markey, 'The British Labour Party and the Australian Labor Party compared', p. 29.

43. Markey, 'Australia', pp. 581-85; Markey, Making of the Labor Party in NSW, chs 1-3; E. Fry, The Condition of the Urban Wage Earning Class in Australia in the 1880s, unpublished PhD thesis, Australian National University, 1956; N. Butlin, Investment in Australian Economic Development, 1861-1900, Canberra, 1964; R.W. Connell and T.H. Irving, Class Structure in Australian History: Documents, Narrative and Argument, Longman Cheshire, Melbourne, 1980, pp. 188-94.

44. Miles Fairburn, 'Why did the New Zealand Labour Party fail to win office until 1935?', Political Science, vol. 37, no. 2, 1985, pp. 116-17; T. Brooking, 'Economic transformation', in H. Oliver and B.R. Williams (eds), The Oxford History of New Zealand, Oxford University Press, Wellington, 1981, p. 246.

45. Olssen, 'New Zealand', p. 610.

46. Fairburn, 'Why did the NZLP fail until 1935?', pp. 116-17.

47. Olssen, Red Feds, pp. 124-80.

48. Markey, 'Australia', p. 580; K. Buckley and E. Wheelwright, No Paradise for Workers: Capitalism and the Common People in Australia, 1788-1914, Oxford University Press, Melbourne, 1988, pp. 152-53.

49. Hagan and Turner, History of the Labor Party in NSW, pp. 118, 122, 130, 175, 184, 238.

50. Ibid., pp. 108, 114; K. Buckley and E. Wheelwright, False Paradise: Australian Capitalism Revisited, 1915-55, Oxford University Press, Melbourne, 1998, pp. 22-23; S. Macintyre, The Oxford History of Australia, Vol. 4: The Succeeding Age, 1901-1942, Oxford University Press, Melbourne, 1986, pp. 17273.

51. T. Coogan, Wherever Green Is Worn: The Story of the Irish Diaspora, Hutchinson, London, 2001, pp. 492-6.

52. Miles Fairburn and Stephen Haslett, 'Cleavage within the working class? The working-class vote for the Labour Party in New Zealand, 1911-51', Labour History, no. 88, May 2005, p. 198.

53. Miles Fairburn and Stephen Haslett, 'The rise of the Left and working-class voting behaviour in New Zealand: new methods', The Journal of Interdisciplinary History, vol. 35, no. 4, 2005, p. 547;

Olssen, 'Origins of the Labour Party', p. 87; Markey, Making of the Labor Party in NSW, p. 191.

54. R. Markey, 'Explaining union mobilisation in the 1880s and early 1900s', Labour History, no. 83, November 2002, pp. 19-42.

55. Olssen, 'Origins of the Labour Party', pp. 82-88; Fairburn, 'Why did the NZLP fail until 1935?', pp. 108-109; Olssen, The Red Feds, pp. 53-123.

56. Markey, Making of the Labour Party in NSW, pp. 176-79; Roydhouse and Taperell, The Labour Party in NSW, pp. 22-51; the various state contributions each provide short biographies of early Labor members in Murphy, Labor in Politics; Gustafson, Labour's Path to Political Independence, pp. 153-69.

57. R. Markey, 'Social democracy and the agrarian issue: Australia 1870-1914', in A. Blok, K. Hitchins, R. Markey and B. Simonson (eds), Urban Radicals, Rural Allies: Social Democracy and the Agrarian Issue, 1870-1914, Peter Lang, Bern, 2002, pp. 111-44; Markey, Making of the Labor Party in NSW, pp. 176-79, 184-92; C.A. Hughes, 'Labor in the electorates', in Murphy et al., Prelude to Power, pp. 74-88, and in Murphy et al., Labor in Power, pp. 61-72; Murphy, 'Queensland', pp. 127-215; Bongiorno, The People's Party, ch.3.

58. J. Hallam, The Untold Story: Labor in Rural NSW, Allen and Unwin, Sydney, 1983.

59. Fairburn, 'Why did the NZLP fail until 1935?', p. 106; E. Olssen, 'The New Zealand labour movement, 1920-40', in Fry, Common Cause, p. 18; J. Martin, Tatau Tatau - One Big Union Together: The Shearers and the Early Years of the NZ Workers' Union, NZ Workers Union, Wellington, 1987, pp. 26-42, 49-56.

60. R. Chapman, The Significance of the 1928 General Election, unpublished MA thesis, University of Auckland, 1948, p. 157; R. Chapman, 'From Labour to National', in G. Rice (ed.), Oxford History of New Zealand, Oxford University Press, Auckland, 2000, pp. 353-54.

61. Brown, Rise of New Zealand Labour, pp. 42, 181.

62. The Liberal Party changed its name to the United Party in 1928.

63. R. Chapman, The Political Scene 1919-1931, Heinemann, Auckland, 1969; Fairburn, 'Why did the NZLP fail until 1935?', p. 103.

64. Fairburn, 'Why did the NZLP fail until 1935?', pp. 103-4, 107.

65. Brown, Rise of New Zealand Labour, p. 6.

66. Fairburn, 'Why did the NZLP fail until 1935?', pp. 114-24.

67. Olssen, 'Origins of the Labour Party', p. 83. 
68. M. Fairburn and S. Haslett, 'Cleavage within the working class? The working-class vote for the Labour Party in New Zealand, 1911-51', Labour History, no. 88, 2005, pp. 183-214; Fairburn and Haslett, 'The rise of the Left and working-class voting behaviour in New Zealand: new methods'; Miles Fairburn and Erik Olssen (eds), Class, Gender and the Vote, Otago University Press, Dunedin, 2005, pp. 11-12; E. Olssen and H. James, 'Social mobility and class formation: the worklife social mobility of men in a New Zealand suburb, 1902-28', International Review of Social History, vol. 44, issue 3, December 1999, pp. 419-49.

69. S. McLeod, 'Did farmers really "lurch towards the Left" in 1935?', in M. Fairburn and E. Olssen (eds), Class, Gender and the Vote, Otago University Press, Dunedin, 2005, pp. 143-58.

70. Olssen, 'Origins of the Labour Party', pp. 83-86; Olssen and James, 'Social mobility and class formation'.

71. Fairburn, 'Why did the NZLParty fail until 1935?', pp. 101- 24; Fairburn and Haslett, 'Cleavage within the working class?', pp. 183-213; Fairburn and Haslett, 'The rise of the Left and workingclass voting behaviour in New Zealand: new methods', pp. 523-55.

72. Fairburn and Haslett, 'Cleavage within the working class?', p. 185.

73. F. Castles, R. Gerritsen, and J. Vowles, 'Introduction', in F. Castles, R. Gerritsen, and J. Vowles (eds), The Great Experiment: Labour Parties and Public Transformation in Australia and New Zealand, Auckland University Press, Auckland, 1996, p. 6.

74. A. Scott, Fading Loyalties: The Australian Labor Party and the Working Class, Pluto Press, Sydney, 1991, p. 28.

75. J. Vowles, 'Party strategies and class composition: the New Zealand Labour and National Parties in 1988 and beyond', New Zealand Sociology, vol. 7, no. 1, May 1992, pp. 38-41; P. Oliver, 'Steady as she goes', New Zealand Herald, 2 June 2007.

76. B. Gustafson, Social Change and Party Organisation: The New Zealand Labour Party Since 1945, Sage Publications, London, 1976, pp. 33-4.

77. B. Gustafson, 'The Labour Party', in H. Gold (ed.), New Zealand Politics in Perspective, Longman Paul, Auckland, 1989, p. 176.

78. J. Vowles, 'Party strategies and class composition', pp. 44-45.

79. Gustafson, 'The Labour Party', p. 176.

80. J. Vowles and I. McAllister, 'Electoral foundations and electoral consequences: from convergence to divergence', in Castles, Gerritsen, and Vowles, The Great Experiment, p. 194.

81. A. Scott, Running on Empty. The Modernisation of the British and Australian Labour Parties, Pluto Press, Sydney, 2000; C. Pierson, "Social democracy on the back foot": the ALP and the "new" Australian model', New Political Economy, vol. 7, no.2, July 2002, pp. 179-97.

82. Recent analyses include J. Singleton, P. Martyn and I. Ward, 'Did the 1996 federal election see a blue-collar revolt against Labor? A Queensland case-study', Australian Journal of Political Science, vol. 33, no. 1, March 1998, pp. 117-30; D. Charnock, 'Spatial variations, contextual and social structural influences on voting for the ALP at the 1996 federal elections: conclusions from multilevel analyses', Australian Journal of Political Science, vol. 32, no. 2, July 1997, pp. 234-54.

83. For example, Scott, Fading Loyalties.

84. Vowles and McAllister, 'Electoral foundations and electoral consequences', p. 195; P. Aimer and J. Vowles, 'What happened at the 2002 election?', in J. Vowles, P. Aimer, S. Banducci, J. Karp, and R. Miller (eds), Voter's Veto, Auckland University Press, Auckland, 2004, pp. 26-27.

85. Markey and James, 'The British Labour Party and the Australian Labor Party compared', p. 29; Olssen, 'The New Zealand Labour Movement, 1920-40', pp. 25-26. Compare with E. Hobsbawm and others, The Forward March of Labour Halted?, Verso, London, 1981.

86. Australian Bureau of Statistics, Employee Earnings, Benefits and Trade Union Membership, Australia, August 2006, Cat. 6310.0, April 2007; Markey, In Case of Oppression, p. 566; B. Ellem and P. Franks, 'Trade union structure and politics in Australia and New Zealand', Labour History, no. 95, November 2008, Table 1.

87. Markey, Making of the Labor Party in NSW, pp. 205-6.

88. Gustafson, Labour's Path to Political Independence, p. 93; R. Dalziel, 'Auckland Women's Political League, 1894-1925', in A. Else (ed.), Women Together: A History of Women's Organisations in New Zealand, Historical Branch, Department of Internal Affairs and Daphne Brasell Associates Press, Wellington, 1993, p. 80.

89. L.F. Crisp, The Australian Federal Labour Party 1901-1951, Hale \& Iremonger, Sydney, 1978 (originally published 1955), pp. 71-77; McMullin, Light on the Hill, pp. 63-64; various state contributions in Parkin and Warhurst, Machine Politics in the ALP, and Murphy, Labor in Politics.

90. Milne, Political Parties in New Zealand, p. 182; Dalziel, 'Auckland Women's Political League, 18941925 ', p. 80; R. Dalziel, 'Political organisations', in Else, Women Together, p. 59.

91. M. Nolan, 'Employment organisations', in Else, Women Together, pp. 196-97; M. Street, 'Working women and trade unions in New Zealand 1889-1906', in P. Walsh (ed.), Trade Unions, Work and Society: The Centenary of the Arbitration System, Dunmore Press, Palmerston North, 1994, pp. 3968; Roth, Trade Unions in New Zealand, pp. 128-33; S. Robertson, 'Women workers and the New Zealand Arbitration Court, 1894-1920', in R. Frances and B. Scates (eds), Women, Work and the Labour Movement in Australia and Aotearoa/New Zealand, special issue of Labour History, no. 61, November 1991, pp. 30-41; R. Markey, 'Women and labour, NSW 1880-1900', in E. Windschuttle 
(ed.), Women, Class and History: Feminist Perspectives on Australia, 1788-1978, Collins, Melbourne, 1980, pp. 83-111; E. Ryan and E. Conlon, Gentle Invaders: Australian Women at Work, 1788-1974, Nelson, Melbourne, 1975; Bongiorno, The People's Party, pp. 115-19.

92. K. Deverall, R. Huntley, P. Sharpe and J. Tilly (eds), Party Girls: Labor Women Now, Pluto Press, Sydney, 2000; M. Simms, 'Women in Caucus', in J. Faulkner and S. Macintyre (eds), True Believers: The Story of the Federal Parliamentary Labor Party, Allen and Unwin, Sydney, 2001, pp. 219-35; various contributions in Parkin and Warhurst, Machine Politics.

93. R. Julian, 'Labour women's council', in Else, Women Together, pp. 102-103; H. Devere and J. Scott, 'The women's movement', in Miller, New Zealand Government and Politics, pp. 392-3.

94. Gustafson, 'The Labour Party', p. 271; R. Gollan, 'The ideology of the labour movement', in E.L. Wheelwright and K. Buckley (eds), Essays in the Political Economy of Australian Capitalism, vol. 1, ANZ Book Co., Sydney, 1975, pp. 206-7; James and Markey, 'Class and labour', pp. 31-2; Murphy, 'Queensland', pp. 129, 208.

95. Gollan, Radical and Working Class Politics, pp. 85-91; Bongiorno, The People's Party, pp. 10-30; Markey, Making of the Labor Party in NSW, pp. 110-20, 211, 225, 243; R. Archer, 'American liberalism and labour politics: labour leaders and liberty language in late nineteenth century Australia and the United States', Labour History, no. 92, May 2007, pp. 1-16; Bennett, 'Rats and Revolutionaries', pp. 59-60; Goldfinch and Mein Smith, 'Compulsory arbitration and the Australasian model of state development, pp. 421-2.

96. W. Pember Reeves, State Experiments in Australia and New Zealand, vol. 2, Macmillan, Melbourne 1969 (originally published 1902), pp. 43-180; S. Macintyre and R. Mitchell, 'Introduction', in Macintyre and Mitchell, Foundations of Arbitration, pp. 10-12; S. Macintyre, 'Neither capital nor labour: the politics of the establishment of arbitration', in Macintyre and Mitchell, Foundations of Arbitration, pp. 178-202; Rickard, Class and Politics, pp. 206-9, 282-5; Goldfinch and Mein Smith, 'Compulsory arbitration and the Australasian model of state development', pp. 422-6, 432-6.

97. Gollan, Radical and Working Class Politics, pp. 151-53, 161-62; Reeves, State Experiments, vol. 2, ch. 2; R. Markey, 'The ALP and the emergence of a national social policy, 1880-1910', in R. Kennedy, Australian Welfare History. Critical Essays, Macmillan, Melbourne, 1982, pp. 116-17; Rickard, Class and Politics, p. 113.

98. Reeves, State Experiments, vol. 2, pp. 1-69; Rickard, Class and Politics, pp. 135-6, 89-103, 105-10; Gollan, Radical and Working Class Politics, pp. 156, 158-9; Nairn, Civilising Capitalism, pp. 158-9.

99. S. Macintyre, "Early Socialism and Labor', Intervention, no. 8, March 1977, pp. 81-87; V. Burgmann, 'Premature labour: the Maritime Strike and the parliamentary strategy', in J. Hagan and A. Wells (eds), The Maritime Strike: A Centennial Retrospective, Five Islands Press, Wollongong, 1992, pp. 8396.

100. J. Saville, 'The ideology of labourism', in R. Benewick, R. Berkhi and B. Parekh (eds), Knowledge and Belief in Politics, Allen and Unwin, London, 1973, pp. 213-26.

101. T. Irving, 'The roots of parliamentary socialism in Australia, 1850-1920', Labour History, no. 67, November 1994, pp. 97-104; V. Burgmann, In Our Time. Socialism and the Rise of Labor, 18851905, Allen and Unwin, Sydney, 1985; Markey, Making of the Labor Party in NSW, ch. 8; Murphy, 'Queensland', pp. 129, 140-42, 208, 210.

102. Gustafson, 'The Labour Party', p. 271; Bennett, 'Rats and Revolutionaries', pp. 139-40; Vowles, 'Ideology and the formation of the New Zealand Labour Party'.

103. J. Vowles, 'From syndicalism to guild socialism', in J. Martin and K. Taylor (ed.), Culture and the Labour Movement, Dunmore Press, Palmerston North, 1991, pp. 283-4.

104. Markey, Making of the Labor Party, pp. 297-304; Scates, A New Australia, pp. 12-18, 106-10.

105. E. Olssen, 'The New Zealand labour movement, 1920-40', p. 21; Bennett, 'Rats and Revolutionaries', pp. 140-43; P. Love, Labor and the Money Power: Australian Labor Populism, 1890-1950, Melbourne University Press, Melbourne, 1984, pp. 134-9.

106. T. Irving, 'Labourism: a political genealogy', Labour History, no. 66, May 1994, pp. 1-14; T. Battin, 'Keynesianism, socialism and labourism and the role of ideas in Labor ideology', ibid., pp. 33-44. See also N. Massey, 'A century of Laborism and the state, 1891-1993: an historical interpretation', ibid., pp. 45-72.

107. Gustafson, 'The Labour Party', p. 271.

108. J. Hagan, The History of the ACTU, Longman Cheshire, Melbourne, 1981, p. 45.

109. Bennett, 'Rats and Revolutionaries', p. 139.

110. Nairn, Civilising Capitalism.

111. A. Métin, Socialism Without Doctrine, Alternative Publishing Cooperative, Sydney, 1977 (originally published 1901), translation by R. Ward.

112. Irving, 'The roots of parliamentary socialism in Australia'.

113. Bennett, 'Rats and Revolutionaries', p. 57; Gollan, Radical and Working Class Politics, pp. 151-69; 18492, 201-8; Rickard, Class and Politics, ch. 4; S. Macintyre, The Labour Experiment, McPhee Gribble, Melbourne, 1989; S. Macintyre, Winners and Losers: The Pursuit of Social Justice in Australian History, Allen and Unwin, Sydney, 1985, ch. 3; Markey, 'Australia', pp. 601-06; R. Markey, 'A century of Labour and Labor, NSW 1890-1990', in M. Easson (ed.), The Foundation of Labor, Lloyd Ross Forum and Pluto Press, Sydney, 1990, pp. 44-45; P.G. McCarthy, The Harvester Judgment: An Historical Assessment, unpublished PhD thesis, Australian National University, Canberra, 1967, 
ch. 4; Goldfinch and Mein Smith, 'Compulsory arbitration and the Australasian model of state development', pp. 426-8, 432, 436, 439; M. Nolan and P. Walsh, 'Labour's leg-iron? Assessing trade unions and arbitration in New Zealand', in P. Walsh (ed.), Trade Unions, Work and Society: The Centenary of the Arbitration System, Dunmore Press, Palmerston North, 1994, pp. 19-25; M. Costa and M. Duffy, Labor, Prosperity and the Nineties: Beyond the Bonsai Economy, Federation Press, Sydney, 1991, chs. 2-3; J. Deeks and E. Rasmussen, Employment Relations in New Zealand, Pearson, Auckland, 2002, pp. 40-49; Gustafson, 'The Labour Party', p. 200; R.A. Epstein, 'Employment and Labour law reform in New Zealand', Case Western Reserve Journal of International Law, vol. 33, no. 3, Summer 2001, p. 364.

114. Goldfinch and Mein Smith, 'Compulsory arbitration and the Australasian model of state development, p. 422; P. Mein Smith, A Concise History of New Zealand, Cambridge University Press, Cambridge, 2005, pp. 98-102.

115. Macintyre, Winners and Losers, ch.5; G.R. Hawke, 'The growth of the economy', in Oliver and Williams, The Oxford History of New Zealand, pp. 369, 375, 379-83.

116. F. Castles, The Working Class and Welfare: Reflections on the Political Development of the Welfare State in Australia and New Zealand, 1890-1980, Allen and Unwin, Wellington, 1985; F. Castles, Australian Public Policy and Economic Vulnerability: A Comparative and Historical Perspective, Allen and Unwin, Sydney, 1988.

117. Markey, 'The ALP and the emergence of a national social policy', pp. 116-8.

118. Markey, Making of the Labor Party in NSW, p. 235.

119. G. Ramia and N. Wailes, 'Knitting the social safety net: reassessing the role of federation in shaping social protection, 1901-14', in M. Hearn and G. Patmore (eds), Working the Nation: Working Life and Federation, 1890-1914, Pluto Press, Sydney, 2001, pp. 136-60; Bennett, 'Rats and Revolutionaries', pp. 135-6.

120. R. Miller, 'Labour', in Miller, New Zealand Government and Politics, pp. 238-39.

121. Ibid., p. 240.

122. Markey, Making of the Labor Party in NSW, pp. 312-4; Gollan, Radical and Working Class Politics, pp. 116-7, 162-4, 194-6; R. Markey, 'Race and organized Labor in Australia, 1850-1901', The Historian, vol. 58, no. 2, Winter 1996, pp. 343-60.

123. E. Olssen, 'The New Zealand Labour movement and race', in M. van der Linden and J. Lucassen (eds), Racism and the Labour Market: Historical Studies, Peter Lang, Bern, 1995, pp. 373-90; Bennett, 'Rats and Revolutionaries', pp. 42-56; C. Price, The Great White Walls Are Built: Restrictive Immigration to North America and Australasia, 1836-88, ANU Press, Canberra, 1974, pp. 199-214; A. Ward, A Show of Justice: Racial 'amalgamation' in nineteenth century New Zealand, ANU Press, Canberra, 1974.

124. G. Patmore and D. Coates, 'Labour parties and the state in Australia and the UK', Labour History, no. 88, May 2005, pp. 121-42.

125. Details of respective State platforms in Murphy, Labor in Politics; Nairn, Civilising Capitalism provides a running commentary for the 1890s in NSW. Also Gollan, Radical and Working Class Politics, ch. 10; Markey, Making of the Labor Party, chs. 7-9; and for early socialist influence on Labor parties, Burgmann, In Our Time.

126. For history of the socialist objective: Crisp, The Australian Federal Labour Party, 1905-1951, ch. 14; B. O'Meagher (ed.), The Socialist Objective: Labor and Socialism, Hale and Iremonger, Sydney, 1983.

127. Gustafson, Labour's Path to Political Independence, p. 93; Gustafson, 'The Labour Party', p. 268; Brown, Rise of New Zealand Labour, pp. 87-94.

128. Murphy, Labor in Politics, passim; D. Murphy, 'State enterprises', in Murphy et al., Labor in Power, pp. 138-56; Markey, In Case of Oppression, pp. 116, 160, 227.

129. R. Gollan, The Commonwealth Bank of Australia: Origins and Early History, ANU Press, Canberra, 1968.

130. Love, Labor and the Money Power; Bennett, 'Rats and Revolutionaries', pp. 122-9, 136-8.

131. Bennett, 'Rats and Revolutionaries', p. 127; Brooking, 'Economic transformation', p. 245; Chapman, 'From Labour to National', p. 352; Sinclair, A History of New Zealand, p. 276.

132. Love, Labor and the Money Power, pp. 165-80; A.L. May, The Battle for the Banks, Sydney University Press, Sydney, 1968; T. Sheridan, Division of Labour. Industrial Relations in the Chifley Years, 1945-49, Oxford University Press, Melbourne, 1989, pp. 27-29.

133. Sinclair, A History of New Zealand, p. 276; Chapman, 'From Labour to National', pp. 341, 352; Olssen, 'The New Zealand Labour Movement, 1920-40', pp. 22-24.

134. Bolton, Oxford History of Australia, 1942-1988, p. 38.

135. Ibid., pp. 77, 161; Chapman, 'From Labour to National', pp. 335, 341, 356-68.

136. See F. Farrell, International Socialism and Australian Labour: The Left in Australia, Hale and Iremonger, Sydney, 1981; I. Turner, Industrial Labour and Politics. The Dynamics of the Labour Movement in Eastern Australia, 1900-21, ANU Press, Canberra, 1965; V. Burgmann, Revolutionary Industrial Unionism: The Industrial Workers of the World, Cambridge University Press, Melbourne, 1995; S. Macintyre, The Reds: The Communist Party of Australia from Origins to Illegality, Allen and Unwin, Sydney, 1998.

137. Gustafson, 'The Labour Party', p. 269; Crisp, The Australian Federal Labour Party, pp. 176-7; Markey, In Case of Oppression, pp. 238-40.

138. Markey, In Case of Oppression, pp. 256-60; Hagan and Turner, History of the Labor Party in NSW, pp. 85-8; G. Robinson, How Labor governed: social structures and the formation of public policy 
during the NSW Lang government of May 1930 to May 1932, unpublished PhD thesis, Monash University, 2001, Part 2.

139. Bennett, 'Rats and Revolutionaries', pp. 121-4, 131-5.

140. This account is based upon R. Fitzgerald, The Pope's Battalions: Santamaria, Catholicism and the Labor Split, University of Queensland Press, St Lucia, 2003; B. Duncan, Crusade or Conspiracy? Catholics and the Anti-Communist Struggle in Australia, UNSW Press, Sydney, 2001; R. Murray, The Split: Australian Labor in the 1950s, Cheshire, Melbourne, 1970; McMullin, Light on the Hill, ch. 11; Markey, In Case of Oppression, pp. 299-309, 331-4; P. Ormonde, Santamaria: The Politics of Fear, Spectrum, Melbourne, 2000.

141. Fitzgerald and Thornton, Labor in Queensland, pp. 141-55.

142. M. Grattan, 'Caucus and the factions', in Faulkner and Macintyre, True Believers, pp. 250-64; McMullin, Light on the Hill, pp. 412-17, 440; various contributions in Parkin and Warhurst, Machine Politics.

143. Cited in Grattan, 'Caucus and the factions', p. 260.

144. Castles, Gerritsen, and Vowles, The Great Experiment; Patmore and Coates, 'Labour parties and the state in Australia and the UK', pp. 129-39.

145. O'Meagher, The Socialist Objective, p. ix, and C. Lloyd, 'The Federal ALP. Supreme or secondary?', in Parkin and Warhurst, Machine Politics, pp. 244-5.

146. Kelly, The End of Certainty; G. Maddox, The Hawke Government and Labor Tradition, Penguin, Ringwood, 1989; G. Singleton, The Accord and the Australian Labour Movement, Melbourne University Press, Melbourne, 1990; S. Carney, Australia in Accord: Politics and Industrial Relations Under the Hawke Government, Macmillan, Melbourne, 1988; K. Wilson, J. Bradford and M. Fitzpatrick, Australia in Accord. An Evaluation of the Prices and Incomes Accord in the Hawke-Keating Years, South Pacific, Melbourne, 2000; P. Ewer, I. Hampson, C. Lloyd, J. Rainford, S. Rix and M. Smith, Politics and the Accord, Pluto Press, Sydney, 1991; G. Mahony (ed.), The Australian Economy Under Labor, Allen and Unwin, Sydney, 1993.

147. Gustafson, 'The Labour Party', p. 272.

148. Miller, 'Labour', pp. 239, 242, 248.

149. See N. Haworth, 'Beyond the Employment Relations Act: the wider agenda for employment relations and social equity in New Zealand', in E. Rasmussen (ed.), Employment Relationships: New Zealand's Employment Relations Act, University of Auckland Press, Auckland, 2004, pp. 190-205. 